\title{
Structural asymmetries and the health crisis: the imperative of a transformative recovery for the advancement of sustainable development in Latin America and the Caribbean ${ }^{1}$
}

\author{
Alicia Bárcena and Mario Cimoli
}

\begin{abstract}
This article underscores the pressing need to transition to a new development model in Latin America and the Caribbean as the region strives to cope with the current health emergency. Statistics show that the Latin American and Caribbean region has been hit harder by the pandemic than any other and that it has also sustained the most damage in economic and social terms. This is attributable to long-standing structural factors that set the stage for the emergence of its present dysfunctional development pattern. The region grew by a scant 0.4\% per year between 2014 and 2019 against the backdrop of a widening external productivity gap, deepening structural heterogeneity, low-productivity development paths and a declining share of wages in GDP. All this has eroded its social and economic development process. The economic reactivation effort must therefore be based on a package of coordinated, ambitious structural reforms in the areas of production, fiscal policy and institutional affairs in order to forge an inclusive and sustainable development style.
\end{abstract}

\section{Keywords}

COVID-19, virus, epidemics, economic aspects, economic crisis, health, poverty, unemployment, economic growth, gross domestic product, income distribution

JEL classification

O54, D30, G01, I14

Authors

Alicia Bárcena is the Executive Secretary of the Economic Commission for Latin America and the Caribbean (ECLAC). Email: alicia.barcena@un.org.

Mario Cimoli is the Deputy Executive Secretary of the Economic Commission for Latin America and the Caribbean (ECLAC). Email: mario.cimoli@un.org.

The authors are grateful to Gabriel Porcile, Vianka Aliaga and Cecilia Vera for their comments and contributions and to Claudio Aravena, Pablo Carvallo, Ernesto Espíndola, Nicole Favreau and Fernando Sossdorf for quantitative inputs that have helped to substantiate the lines of reasoning developed here. 


\section{Introduction}

The spread of the coronavirus disease (COVID-19) in Latin America and the Caribbean since March 2020 has not only triggered an extremely serious health emergency that has taken a heavy toll in human lives and has had serious economic and social repercussions. These effects have, in turn, deepened the recessionary bias that the region's economies were displaying even before the outbreak of the health crisis. This bias translates into slow growth, sluggish exports, lower levels of productive investment and higher employment and has, in a number of cases, led to economic stagnation and concomitant setbacks in social areas that are reflected in rising poverty and worsening patterns of factor and personal income distribution. In some countries, the social and economic crises associated with this dynamic have engendered severe political crises that pose a threat to democracy and to the broad social inclusion that is a necessary condition for any virtuous development process.

In response to the outbreak of COVID-19 and the impacts that it has had and is still having, since March 2020 the Economic Commission for Latin America and the Caribbean (ECLAC) has been deploying a major analytical effort to explore the health, social and economic implications of this crisis and to offer policy proposals to its member countries that will help them to reboot the region's economy and set out on a new sustainable development and growth path.

In this article we will analyse the structural factors that explain why this pandemic has had a greater health-related and socioeconomic impact in Latin America and the Caribbean than it has in other regions of the world and will review the studies on this health crisis that have been conducted by ECLAC. We will argue that, because of these structural factors, the region's pre-pandemic development style was unsustainable from a social (inequality), economic (persistent productive and technological asymmetries between the region and more advanced countries) and environmental (use of natural resources and the biosphere in excess of planetary boundaries) standpoint. An integrated approach needs to be taken to the examination of these three factors in order to encompass their multiple interactions. This approach is based on the analytical model of these three (economic, social and environmental) gaps which was proposed by ECLAC at its thirty-eighth session (ECLAC 2020i). This model describes the region's existing growth pattern and its prospects for moving towards a more virtuous growth path.

This article is divided into six sections. Section II offers an analysis of the global scope of the pandemic in terms of its health and economic impacts. Section III delves into the stylized facts associated with the economic dynamics of the region prior to the outbreak of the present health emergency. Section IV presents the three-gap model along with a discussion of the challenges involved in narrowing those gaps under differing sets of political conditions. Section $V$ surveys the social and economic fallout from the crisis, while section VI concludes the analysis with a series of macro-, meso- and microeconomic policy proposals for finding a viable way forward that will set the region on a new development path: a path that will entail changing production patterns and greater social inclusion and environmental sustainability as the region leaves its current dysfunctional development model behind.

\section{The global scope of the pandemic}

\section{Health impacts}

With the rapid spread of COVID-19 around the globe, today our civilization finds itself confronted with a health, social and economic crisis of staggering proportions (ECLAC, 2020a). While the world and the region were able to cope with the outbreaks of human avian influenza ("bird flu") in 2003 and of swine flu in 2009 (transmitted by the H5N1 and H1N1 viruses, respectively), the COVID-19 health emergency 
has necessitated much greater containment efforts and has resulted in more cases and more deaths than any other epidemic since the Spanish flu did a century ago. Data compiled by the World Health Organization (WHO) for the period up to 25 February 2021 indicate that COVID-19 has killed 2,486,679 persons. ${ }^{2}$ By comparison, historical estimates presented by Murillo (2011) indicate that the Spanish flu claimed between 20 million and 40 million lives, while the Hong Kong flu (1968) caused slightly fewer deaths than COVID-19 had up to the cut-off date for this analysis (see table 1).

Table 1

Worldwide deaths caused by flu pandemics in the twentieth and twenty-first centuries (Number of persons)

\begin{tabular}{llcc}
\hline Years & Disease & Deaths & Virus \\
\hline $1918-1919$ & Spanish flu & $20000000-40000000$ & H1N1 \\
\hline $1957-1959$ & Asian flu & 2000000 & H2N2 \\
\hline 1968 & Hong Kong flu & 1000000 & H3N2 \\
\hline $2003^{a}$ & Bird flu & 455 & H5N1 \\
\hline $2009^{b}$ & Swine flu & 18449 & H1N1 \\
\hline $2019-$ & Coronavirus disease & 2486679 & SARS-CoV2 \\
\hline
\end{tabular}

Source: G. Murillo, "Recordando la gripe española", Medicina Interna de México, vol. 27, No. 5, Mexico City, 2011 and World Health Organization (WHO).

a Figures up to 10 July 2020.

b Figures up to 1 August 2010.

Table 2 provides data on the global impact of COVID-19. These figures indicate that, with over 111 million cases on record to date in the world, the regions where the incidence of the disease has been the lowest are Oceania, with somewhat more than 58,000 cases ( $0.1 \%$ of the world total), Africa, with 3,697,776 cases (3.3\%), and the Middle East, with 5,523,592 cases (4.9\%), while the regions where the pandemic has hit the hardest are Europe, with 36,794,659 cases (32.9\%), North America, with 28,807,637 cases (25.7\%), Latin America and the Caribbean, with 21,066,155 cases (18.8\%), and Asia, with 16,051.119 (14.3\%). The trends in the number of deaths more or less mirror the trends in the number of cases, as, here too, Oceania, Africa and the Middle East have registered the fewest COVID-19 deaths, with $0.05 \%, 3.7 \%$ and $4.5 \%$ of the world total, respectively (columns 1 through 4 ).

Table 2

World regions: COVID-19 cases and deaths as of 25 February 2021

(Numbers of persons and percentages)

\begin{tabular}{lccccccc}
\hline \multicolumn{1}{c}{ Region } & $\begin{array}{c}\text { Cases } \\
\text { (number) } \\
(1)\end{array}$ & $\begin{array}{c}\text { Deaths } \\
\text { (number) } \\
(\mathbf{2})\end{array}$ & $\begin{array}{c}\text { Cases } \\
\text { (percentages } \\
\text { of the total) } \\
(3)\end{array}$ & $\begin{array}{c}\text { Deaths } \\
\text { (percentages } \\
\text { of the total) } \\
(4)\end{array}$ & $\begin{array}{c}\text { Cases } \\
\text { (per million } \\
\text { persons) } \\
(5)\end{array}$ & $\begin{array}{c}\text { Deaths } \\
\text { (per million } \\
\text { persons) } \\
(6)\end{array}$ & $\begin{array}{c}\text { Deaths as } \\
\text { a percentage } \\
\text { of all cases } \\
(7)=(6) /(5)^{*} 100\end{array}$ \\
\hline Africa & 3697776 & 91928 & 3.3 & 3.7 & 3056 & 76 & 2.5 \\
\hline North America & 28807637 & 520779 & 25.7 & 20.9 & 78734 & 1423 & 1.8 \\
\hline $\begin{array}{l}\text { Latin America } \\
\text { and the Caribbean }\end{array}$ & 21066155 & 667308 & 18.8 & 26.8 & 32453 & 1028 & 3.2 \\
\hline Asia & 16051119 & 254807 & 14.3 & 10.2 & 3842 & 61 & 1.6 \\
\hline Europe & 36794659 & 837638 & 32.9 & 33.7 & 43399 & 988 & 2.3 \\
\hline Middle East & 5523592 & 112987 & 4.9 & 4.5 & 15668 & 320 & 2.0 \\
\hline Oceania & 58271 & 1219 & 0.1 & 0.0 & 1382 & 29 & 2.1 \\
\hline World & 111999954 & 2486679 & 100 & 100 & 14649 & 325 & 2.2 \\
\hline
\end{tabular}

Source:Prepared by the authors, on the basis of figures provided by the World Health Organization (WHO) [online] https:// worldhealthorg.shinyapps.io/covid/ and World Bank.

2 Data on the pandemic are updated regularly on the WHO website ([online] https://worldhealthorg.shinyapps.io/covid/) but, for the purposes of this article, 25 February 2021 is used as a cut-off date. The data compiled by the Coronavirus Resource Center of John Hopkins University ([online] https://coronavirus.jhu.edu/map.html) exhibit similar trends to those reflected by the WHO figures. 
While Asia has one of the highest incidence rates, its COVID-19 death toll (10.2\% of the world total) is lower than those of other hard-hit regions owing in part to its sound health policies. In North America, with 520,779 deaths (20.9\% of the world total), the United States outpaces Canada in percentage terms in both the number of cases and the number of deaths. Europe, with 837,638 COVID-19 deaths, or $32.9 \%$ of the total, is one of the first regions where the virus began to spread on a large scale after it was detected in China in early 2020 and where it has been the most lethal. Italy and Spain saw the largest number of cases and deaths in the early months of the outbreak while, towards the end of 2020, the Russian Federation, France and the United Kingdom were experiencing high case rates. Although the European countries initially managed to curb the crisis with the help of large-scale health and fiscal support measures and were thus able to relax their lockdowns and travel restrictions, many of these countries have since been hit by further waves that have obliged them to reintroduce the types of measures used during the initial outbreak.

The Latin American and Caribbean region is not only one of the world regions with the most COVID-19 cases, after Europe and North America, but it also has the second-highest COVID-19 death rate in the world, with 667,308 deaths, or $26.8 \%$ of the world total. Columns 5 and 6 of table 2 show the numbers of cases and deaths per million inhabitants in each region. The regions with the most cases per million persons are North America and Europe, followed by Latin America and the Caribbean. In terms of the number of deaths, the order changes, however. North America still heads up the list, with 1,423 deaths per million population, but it is followed by Latin America and the Caribbean $(1,028)$ and then by Europe (988). Above and beyond these differences in adjusted regional totals, however, as may be seen in column 7 of table 2, which shows the number of deaths as a percentage of the total number of cases, the rate for Latin America and the Caribbean, at $3.2 \%$, is the highest of any world region. This more informative measurement of the spread and impact of the virus reflects the greater fragility of the region's health-care systems owing to their fragmentation and insufficient coverage as compared to those of the world's more developed regions.

\section{Economic impacts}

The outbreak of coronavirus disease in the Chinese city of Wuhan in January 2020 soon spread to the rest of the world, reaching pandemic proportions. Governments around the world were forced to order lockdowns and impose social distancing measures in an effort to curb the spread of the virus (ECLAC, 2020a and 2020h). These measures, many of which are still in place, have nearly paralysed the global economy. The lockdown introduced early on in China sent shockwaves through many economies that rely on trade with that country, including those whose pattern of specialization rests on commodities, since both the demand for these products and their prices have fallen, although they were expected to rebound towards the end of the year in some cases. In addition, because of China's dominant position in global value chains, production patterns have undergone changes that have swiftly propagated and affected all the countries involved in those chains (ECLAC, 2020a).

The health crisis has thus turned into an economic crisis of an enormous magnitude, one that is comparable to the severe cyclical crises that overtook capitalism in the twentieth century. As noted by ECLAC in its Economic Survey of Latin America and the Caribbean, 2020, "the COVID-19 pandemic has pushed the global economy into the worst recession since the Second World War" (ECLAC, 2020h, p. 16). In fact, ECLAC (2020j) projects that the global economy will have contracted by $4.4 \%$ in 2020. This trend is illustrated in figure 1, which tracks GDP growth in the major regions and in certain countries that have a strong influence on the world economy. GDP growth in the developed economies, which had already been slowing since 2018, is expected to have plunged by $5.8 \%$ in 2020 . Within this group, even steeper drops of $8.0 \%$ in the euro area economies and of $10.0 \%$ in the United Kingdom are projected, while the United States and Japan are expected to see their GDP shrink by $4.1 \%$ and 5.6\%, respectively. 
Figure 1

Selected regions and countries: GDP growth rates in 2018 and 2019 and projections for 2020 and 2021

(Percentages)

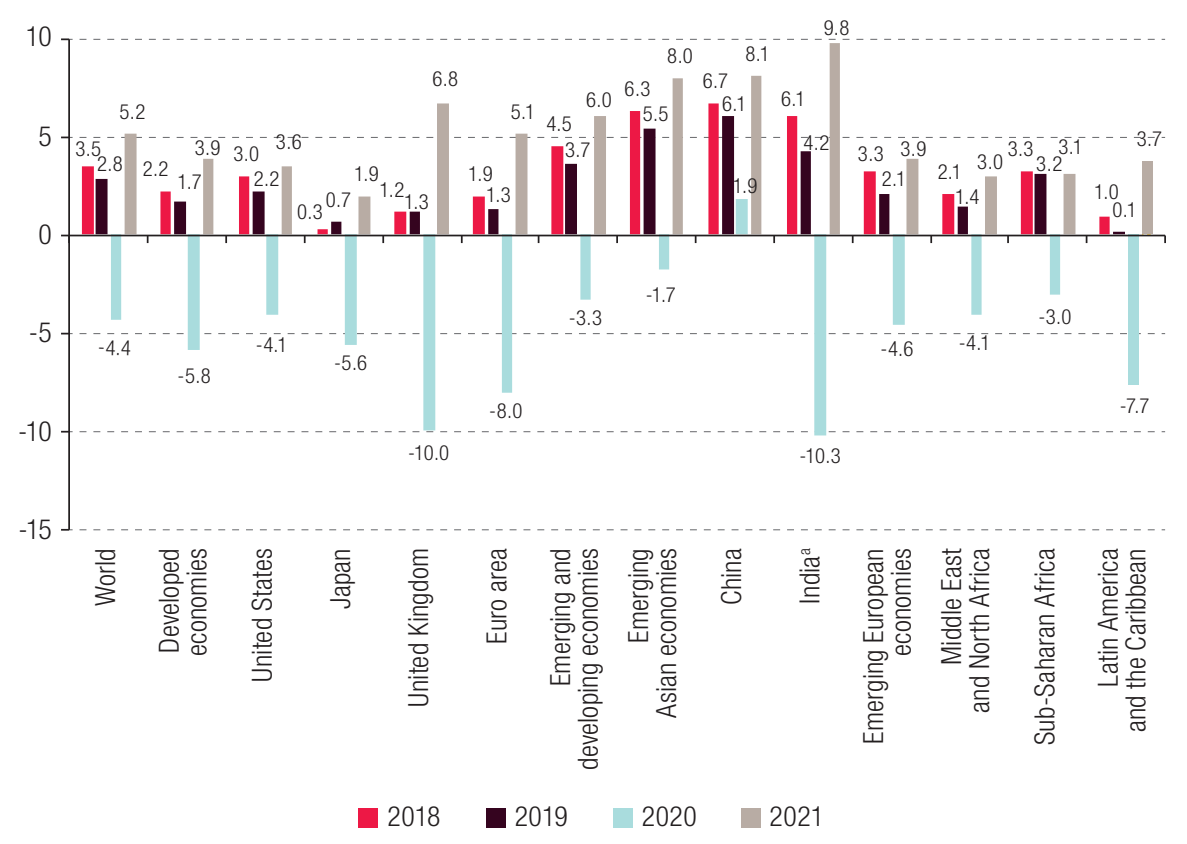

Source: Prepared by the authors on the basis of figures from Economic Commission for Latin America and the Caribbean (ECLAC); World Bank, Global Economic Monitor (GEM) [online database] https://datacatalog.worldbank.org/dataset/global-economicmonitor [accessed on: June 2020]; Organization for Economic Cooperation and Development (OECD), OECD Economic Outlook, Paris, OECD Publishing, June 2020: European Central Bank(ECB), "Eurosystem staff macroeconomic projections", June 2020 [online] https://www.ecb.europa.eu/pub/projections/html/index.en.html; and United Nations, World Economic Situation and Prospects as of mid-2020, New York, 2020.

a The figures for India are for the fiscal year, which begins in April and ends in March of the following calendar year.

Emerging and developing economies are expected to register a smaller contraction (of around -3.3\%), but this will stand in sharp contrast to the growth trend observed in 2018 and 2019. Within this group, the economies of East Asia and the Pacific are estimated to have grown by $1.7 \%$. China's economy will continue to expand, but at a projected rate of only $1.9 \%$, after having buoyed world economic growth in 2018 and 2019 with rates of $6.7 \%$ and $6.1 \%$, respectively. India, meanwhile, is likely to see a contraction of $10.3 \%$, and the economies of the Middle East and North Africa are expected to experience a sizeable drop (-4.1\%) in their GDP as well.

Among the developing economies, those of Latin America and the Caribbean have not only been the most severely affected in terms of the health of the population (see table 2) but have also been the hit the hardest in economic terms (see figure 1), with their GDP plummeting by around $-7.7 \%$. This nosedive in regional production, as will be explained below, is being brought about on the one hand, by the collapse of world trade and weakening international prices for the region's export products and, on the other, by the slump in demand within the economies of the region, which has, in conjunction with widespread lockdowns, driven up unemployment levels and caused many production units to close their doors. As will be discussed later on in this article, these developments are also having a strong impact on society in terms of poverty, extreme poverty and inequality.

Recent ECLAC projections (2020j) point to a resumption of growth both in the world as a whole and in all the regions and countries for which trends have been analysed, however. Nevertheless, a recovery clearly hinges on more effective efforts to contain the pandemic and particularly on the advancement of the national inoculation strategies made possible by international laboratories' swift development of 
COVID-19 vaccines. The prompt roll-out of these strategies could do a great deal to reduce worldwide levels of uncertainty and thus re-energize the production sector, spur economic growth, revive trade and contribute to the recovery of employment levels and capital formation.

World trade has collapsed during the pandemic. The World Trade Organization (WTO) has projected a drop of between 13\% and $32 \%$ in world trade in goods (based on data up to May) (see figure 2). According to figures compiled by ECLAC (2020h), unlike what has occurred in earlier crises, trade in services has been hurt even more than trade in goods. Transport services, in particular, have been badly hurt by the sharp downturn in merchandise trade. In addition, health-related restrictions on international passenger travel have had a massive impact on tourism. Based on data compiled by WTO, ECLAC (2020h) has calculated that activity in the tourism industry plunged by $56 \%$ between January and May 2020, and it is projecting a contraction of between $60 \%$ and $80 \%$ in this sector for the year as a whole.

\section{Figure 2}

Year-on-year variations in the volume of world trade in goods, January 2003 to May 2020

(Percentages based on a seasonally adjusted index)

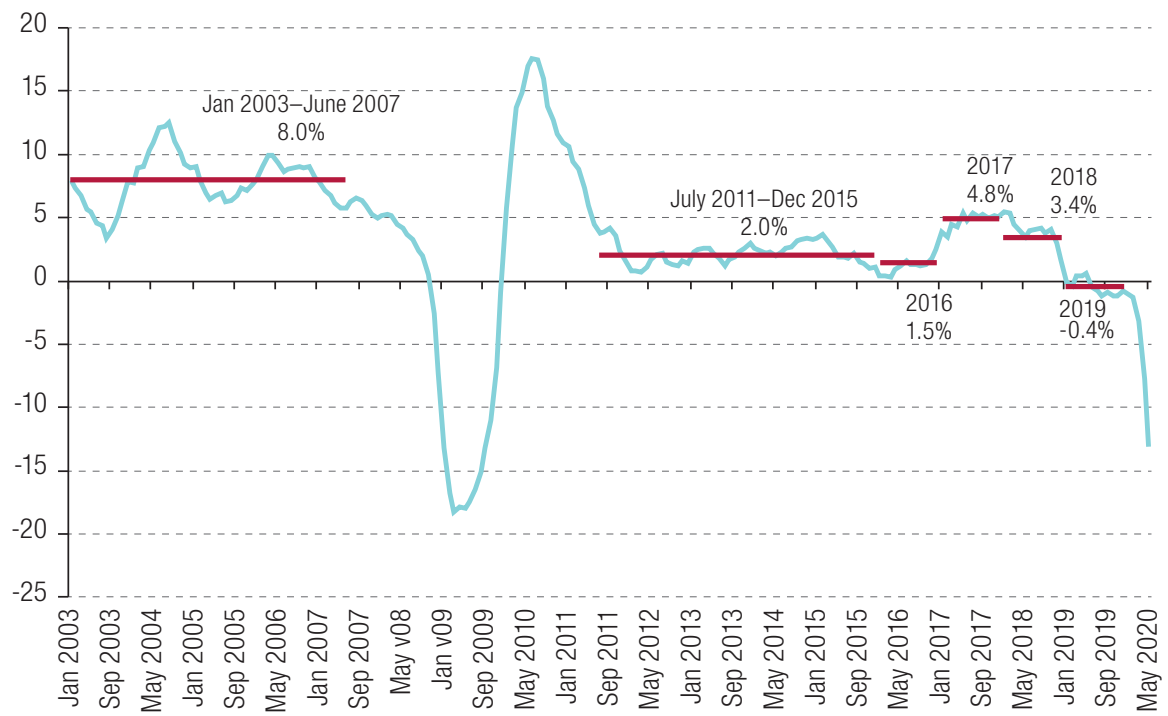

Source: Economic Commission for Latin America and the Caribbean (ECLAC), on the basis of Netherlands Bureau of Economic Policy Analysis (CPB), World Trade Monitor [online database] https://www.cpb.nl/en/worldtrademonitor; World Trade Organization (WTO), "Trade forecast press conference", 8 April 2020 [online] https://www.wto.org/english/news_e/spra_e/ spra303_e.htm.

With global export demand shrinking, according to initial projections for 2020, it was estimated that commodity prices would be sharply lower than they had been in 2019. This would have a negative impact on the terms of trade for commodity-exporting countries. Oil prices were expected to slump by $36 \%$ in 2020. The prices of agricultural products, on the other hand, were forecast to be hurt much less by the crisis, for falling almost $2 \%$. Metal and mineral prices were projected to have dropped by a scant $0.1 \%$ overall, but with sharply differing price trends for individual metals and minerals. Thus, the prices of industrial metals, including copper, were estimated to fall by $5 \%$, but this would be almost completely offset by the rise in the prices of precious metals such as gold, which, at least as of 24 July 2020, had jumped by $28 \%$ (see table 3 ). 
Table 3

Year-on-year variations in annual average commodity prices, 2016-2020

(Percentages)

\begin{tabular}{lrrrrr}
\hline & 2016 & 2017 & 2018 & 2019 & $2020^{\mathrm{a}}$ \\
\hline Agricultural products & 4.9 & 0.5 & 0.5 & -3.0 & -1.7 \\
\hline Food, tropical beverages and oilseeds & 6.8 & -0.6 & -2.8 & -3.7 & -1.5 \\
\hline Food & 11.5 & -0.2 & -4.3 & -0.6 & -2.5 \\
\hline Tropical beverages & 0.6 & -1.7 & -10.1 & -5.0 & 6.5 \\
\hline Oilseeds and oils & 2.4 & -1.0 & 1.4 & -7.7 & -2.0 \\
\hline Forestry and agricultural raw materials & -2.3 & 4.9 & 13.4 & -0.7 & -2.4 \\
\hline Minerals and metals & -0.8 & 23.3 & 4.2 & -1.0 & -0.1 \\
\hline Energy & -16.3 & 23.5 & 25.6 & -9.1 & -29.6 \\
\hline \multicolumn{1}{c}{ Crude petroleum } & -15.7 & 14.5 & 29.4 & -10.2 & -35.6 \\
\hline Commodities - total & -4.0 & 14.5 & 9.8 & -4.6 & -10.9 \\
\hline Commodities other than energy - total & 2.3 & 10.8 & 2.3 & -2.0 & -0.9 \\
\hline
\end{tabular}

Source: Economic Commission for Latin America and the Caribbean (ECLAC), on the basis of World Bank, "World Bank Commodities Price Data (The Pink Sheet)", 2 June 2020 [online] http://pubdocs.worldbank.org/en/774651591120179792/CMO-PinkSheet-June-2020.pdf; United States Energy Information Administration (EIA), Short Term Energy Outlook, 7 July 2020, and data from Bloomberg and Capital Economics.

a The figures for 2020 are projections.

b This category includes petroleum, natural gas and coal.

Governments have adopted a variety of special macroeconomic policy measures, including downward revisions of central bank interest rates, in both developed and emerging economies. The authorities in both of these types of economies have also deployed fiscal stimulus packages of various sizes in an effort to soften the blow for employment and household income. These packages have included, for example, transfer payments to households and businesses, extended grace periods for the payment of taxes and other levies, payroll subsidies, tax cuts and government guarantees for loans and other types of credit.

While conditions have not deteriorated in the financial sector, the level of uncertainty about the health-related, social and economic knock-on effects of the pandemic remains high, and that uncertainty is reflected in the financial market volatility illustrated in figure 3. As measured by the VIX index, market volatility reached an all-time high in mid-March 2020, triggering massive capital outflows from emerging markets and driving up sovereign risk ratings, particularly in emerging markets. Most currencies have depreciated sharply against the United States dollar, given the globally countercyclical nature of that currency, as it tends to strengthen during recessions and to weaken in the face of expectations of reactivations and boom times (see figure 4).

Figure 3

Financial market volatility as measured by the VIX index, 1 January 2007-24 July 2020

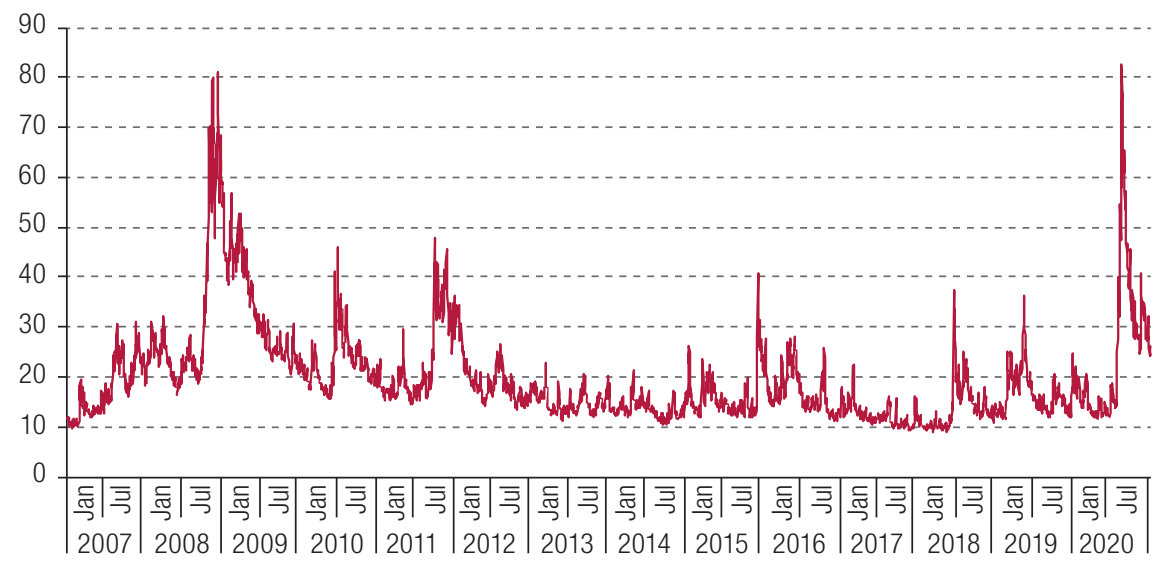

Source:Economic Commission for Latin America and the Caribbean (ECLAC), on the basis of Bloomberg. 
Figure 4

Dollar exchange rate for major currencies, 1 January 2019-16 July 2020

(DXY index; January $2013=100)$

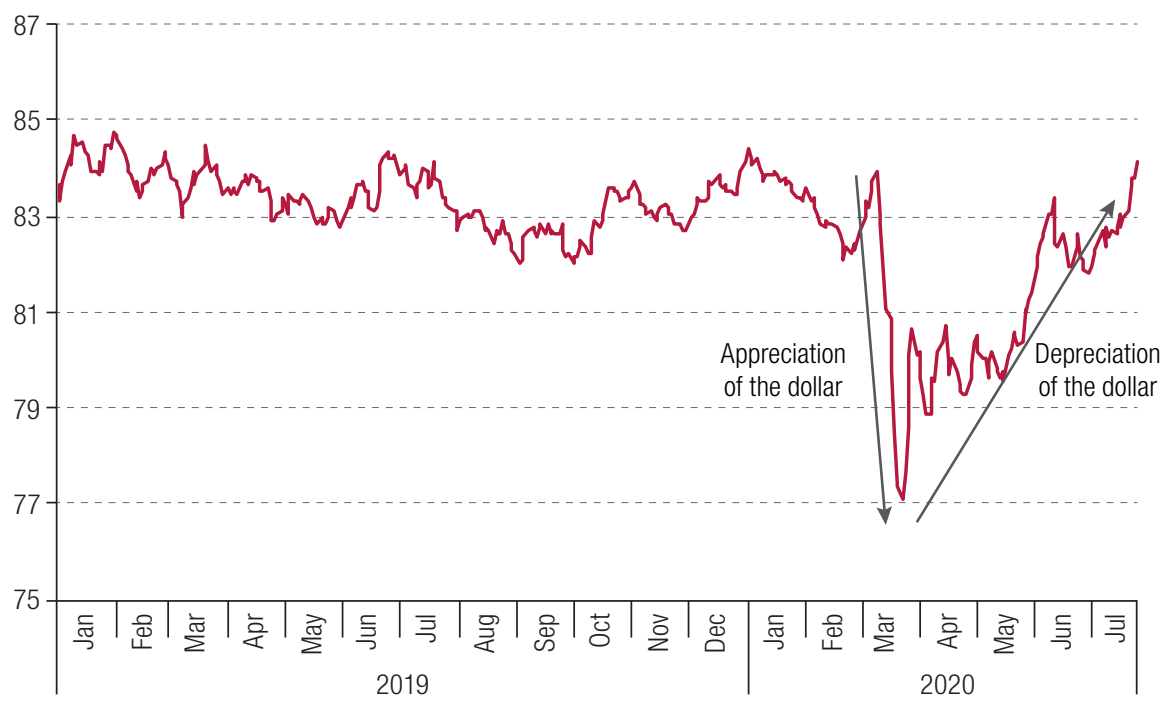

Source: Economic Commission for Latin America and the Caribbean (ECLAC), on the basis of Bloomberg.

Note: The Bloomberg Dollar Spot Index (DXY) tracks the trend in the value of the United States dollar against a basket of 10 leading global currencies.

\section{Latin America and the Caribbean and the health crisis}

Information was provided in section II which indicates that the pandemic has had a greater health-related and economic impact on Latin America and the Caribbean than on any other world region. In this section, we will show how these impacts are the consequence of recessionary factors that were already in evidence in 2014-2019, when the region's average annual growth rate was a paltry $0.4 \%$. Those six years were marked by the continued impact of the recessionary shocks experienced by the world economy as a result of the 2008-2009 global financial crash (what Ocampo (2020) refers to as the "North Atlantic crisis") and the euro area crisis of 2011, the elevated level of financial volatility in global markets, the end of the commodity boom, and recent geopolitical and economic developments such as the worsening trade tensions between China and the United States.

This external environment has exacerbated persistent structural factors that are characteristic of the economies of the region, such as structural heterogeneity or domestic production gaps; balance-of-payments growth constraints; the contraction of effective demand, especially in relation to productive investment; the shift in the composition of the export basket back towards commodities and the lack of complexity in the sectoral production matrix in terms of knowledge, innovation, and research and development (R\&D); limited fiscal space for social and production policies; the deterioration of employment conditions as the informal sector once again expands; and the long-standing shift in factor income distribution away from wages. Even before the crisis, all these elements were translating into social reversals in terms of poverty, extreme poverty and personal (and household) income distribution (see ECLAC, 2020a, 2020b and 2020i, and, in this special edition, Abeles, Pérez Caldentey and Porcile, 2020). A number of stylized facts will be examined in the following discussion that illustrate the internal and external structural features of regional economic dynamics that predate the crisis occasioned by the pandemic. 


\section{Unstable, volatile growth}

Over the long term, GDP growth rates in Latin America and the Caribbean have been lower than those of developed economies and of other peripheral and emerging regions. An even more characteristic feature of the region's lagging development in relative terms is the difficulty it has had in sustaining strong growth rates during economic booms and the relative persistence of slack growth during recessions and reactivations, which signals the presence of real volatility. Figure 5 depicts growth trends in Latin America from 1950 to 2019. A cursory look at the figure shows up two things very clearly: (i) the highest rates registered by the region occurred between 1950 and 1980, which was a period marked by developmentalist policies and State-guided industrialization; and (ii) following the Latin American external debt crisis, which the region began to recover from in 1983, its growth rates regained positive territory and then remained there except in 1990, 2009, 2016 and, as noted in the preceding section, 2020.

\section{Figure 5}

Latin America: real GDP growth rates, 1950-2019

(Percentages)

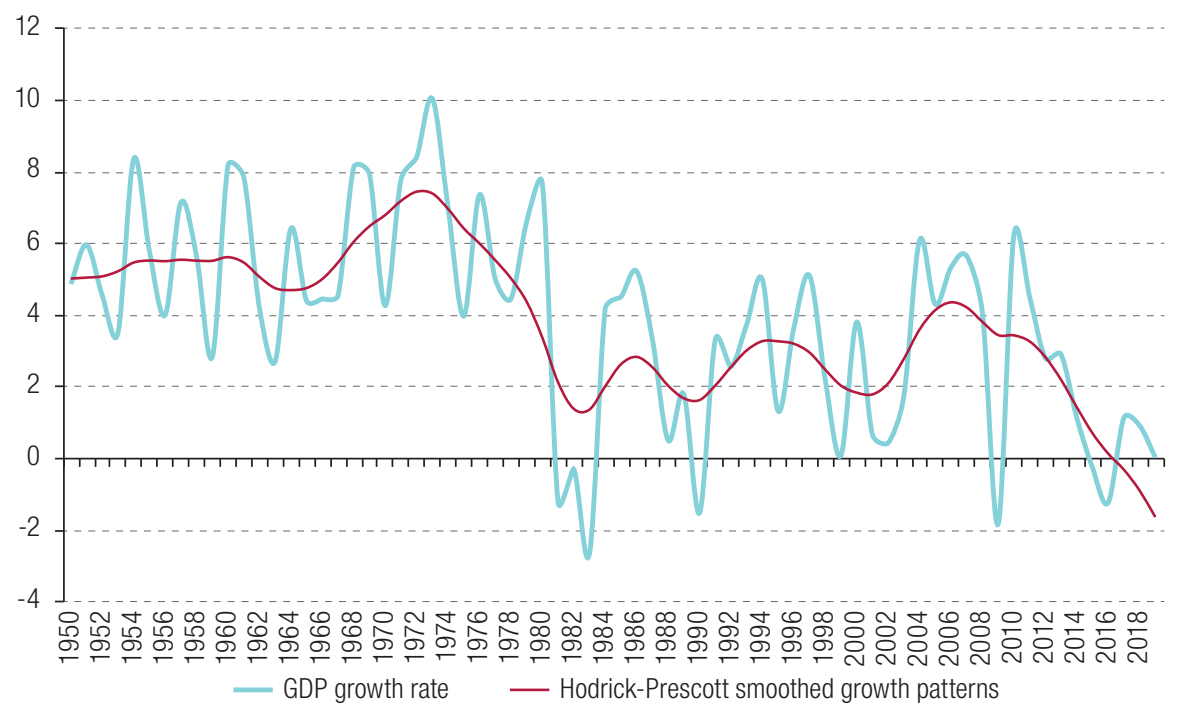

Source: Prepared by the authors, on the basis of figures provided by the Economic Commission for Latin America and the Caribbean (ECLAC).

In the years from 1983 to 2020, the region reverted to a production pattern based on static comparative advantages against the backdrop of a hyperglobalization of the world economy, and growth was slower than in the years leading up to that period. When the Hodrick-Prescott filter is applied to the data on this trend, the persistent variability affecting the region's economies becomes evident, along with the downward trend in growth from the 1980s onward.

A more direct measurement of the volatility of the region's economic growth pattern is presented in figure 6, which plots average effective GDP growth rates in different periods (horizontal axis) and shows their corresponding standard deviations (vertical axis). As the reader will see, the region's growth rates were higher and less volatile in 1950-1979, while they were lower and more volatile in 1980-2020. A reduction in external vulnerability and an increase in the accumulation of domestic production capacities associated with the production policies characteristic of the period of developmentalism may be at the root of the explanation for this turnaround in the region's historical growth patterns. 
Figure 6

Latin America: volatility of growth, 1950-2019

(Percentages and standard deviations)

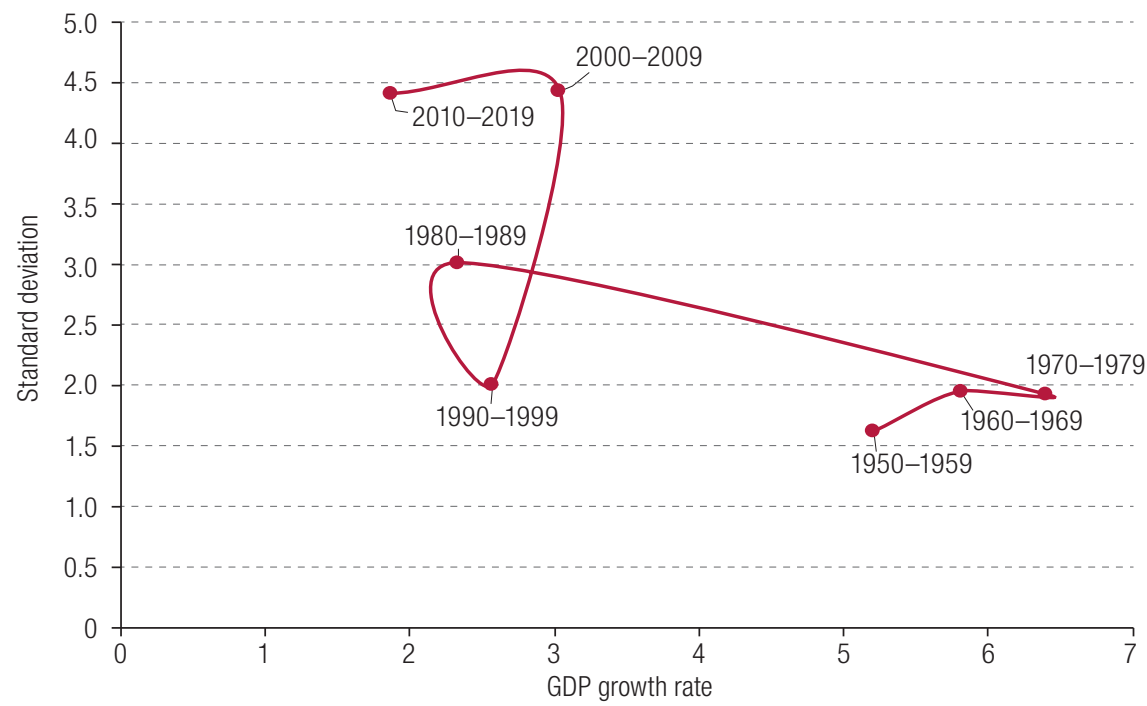

Source:Prepared by the authors, on the basis of figures provided by the Economic Commission for Latin America and the Caribbean (ECLAC).

\section{Growth under external constraints}

Externally constrained growth is one of the most typical stylized facts associated with the region's dysfunctional development pattern. The core component of this concept has to do with peripheral economies' inability to grow at a pace that will allow them to absorb the entire workforce. This gives rise to the high levels of underemployment in low-productivity occupations that is characteristic of development dynamics on the periphery (structural heterogeneity) owing to these economies' very limited potential for generating foreign exchange. Raúl Prebisch's analysis of this issue led him to argue that its cause lay in the fact that the periphery's commodity exports are less income-elastic than are imports of the manufactures produced by the world's central economies are (Prebisch, 1962). Over the long term, this results in a divergence of these two types of economies' growth patterns owing to their productive and technological asymmetries and the external debt pressure exerted on the periphery due to its structural foreign exchange shortages. Prebisch (1963) expanded upon these ideas in developing the concept of external constraint, which he described as a succession of balance-of-payments disequilibria of such a magnitude that shortages of foreign exchange first hindered and later blocked the process of import substitution (Rodríguez, 2006, p. 143).

Seers (1962) and Rodríguez (1977) devised similar approaches to the issue of external constraints, but it was Thirlwall (1979) who formalized the concept of growth rates that were compatible with external equilibrium. In a global economy composed of two regions - a centre and a periphery - that rate is expressed as: $y^{E}=\frac{\varepsilon}{\pi} y^{c}$, where $y^{E}$ and $y^{C}$ represent, respectively, the periphery's and the centre's growth rates; stands for the income elasticity of world demand for exports from the periphery and $\pi$ denotes the income elasticity of imports coming from the centre. These elasticities are determined, in turn, by the ratio between the periphery's and the centre's technological capacities because these are what determine the nature of a country's participation in the markets where domestic and external demand are growing the fastest. The periphery will grow more slowly than the centre and their growth rates will diverge whenever $\frac{\varepsilon}{\pi}$ is less than 1 . This divergence will continue as long as peripheral economies are not able to modify that variable by introducing industrial, production and technology policies to increase it and thus diminish the external constraint. 
The relationship between growth and the external sector is illustrated in figure 7, which plots the trade balance as a percentage of GDP (horizontal axis) and GDP growth (vertical axis). Periods during which the economies grew rapidly while registering a trade deficit are followed by periods of low growth in which the region's economies have had to grow and invest less in order to generate surpluses that would allow them to pay their countries' debts. They managed to grow while maintaining a trade surplus only during the years of rapid industrialization in the 1970s and during the commodities boom, although, in this latter case, growth was slower. The situation that began to take shape at the start of the 2020s, with the outbreak of the pandemic, is an extremely complex one, however.

Figure 7

Latin America: the trade balance as a percentage of GDP and GDP growth rates, 1950-2019 (Percentages)

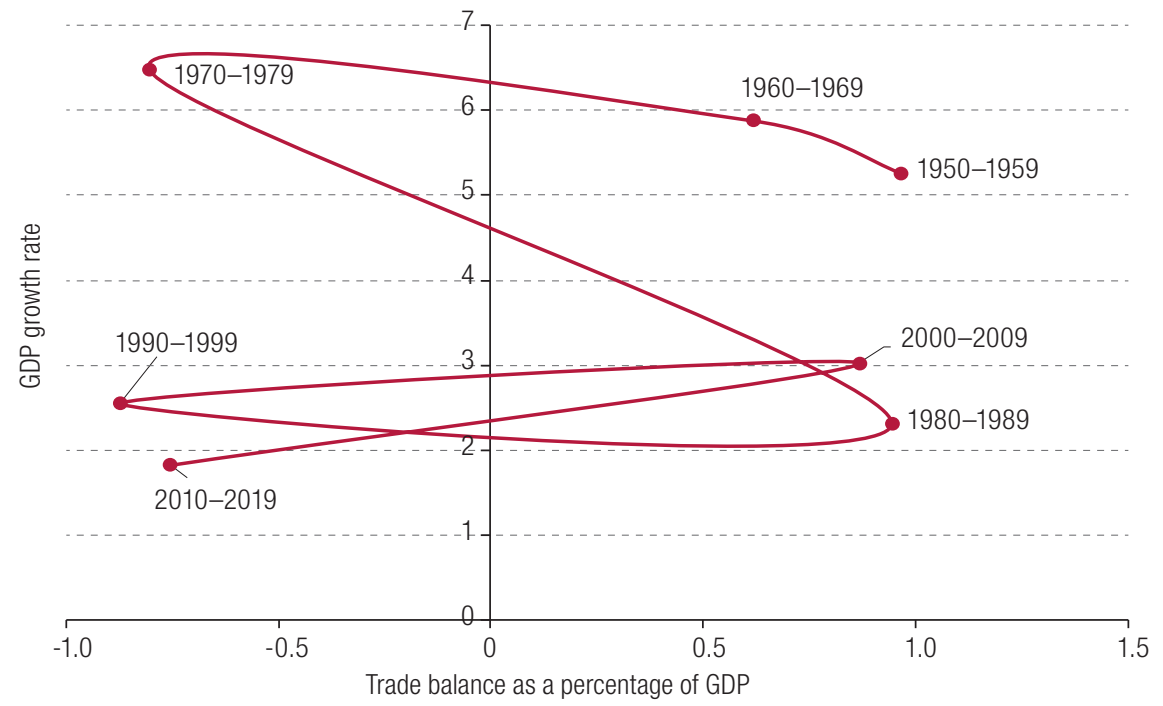

Source:Prepared by the authors, on the basis of figures provided by the Economic Commission for Latin America and the Caribbean (ECLAC).

\section{Low labour productivity as an underlying factor of spurious competitiveness}

In the mid-1980s, Fernando Fajnzylber developed two opposing concepts to characterize the region's competitiveness and development patterns. He described the form of competitiveness based on prices, overvalued exchange rates, depressed wages and static comparative advantages supported by the extraction of natural resources as "spurious competitiveness" and differentiated it from competitiveness based on the incorporation of technical progress into the production process and increasing training-induced labour productivity, which he called "authentic competitiveness" (Fajnzylber, 1990).

Figure 8 provides a breakdown of GDP growth rates for the countries of Latin America and the Caribbean along with other countries and regions in 2000-2019 based on the contributions of employment and labour productivity to GDP growth. ${ }^{3}$ The figure shows that, on average, $76 \%$ of the region's growth over the last two decades has been powered by employment and $24 \%$ by gains in

3 This is calculated using the following procedure: If $Y$ represents the level of GDP and $E$ the level of employment, then mean labour productivity is defined by $P_{E} \equiv \frac{Y}{E}$. Using these definitions, it becomes trivial to express GDP as $Y=P_{E} \cdot E$. By converting this equation into a logarithm and then taking the total differential for time, we have $\hat{Y}=\widehat{P_{E}}+\hat{E}$, where $\hat{Y}$ represents the GDP growth rate, $\widehat{P_{E}}$ the increase in mean labour productivity and $\hat{E}$ the growth of employment. Normalizing the equation by the GDP growth rate, we then find that the contribution of mean labour productivity is $\frac{\widehat{P_{E}}}{\hat{Y}}$ and that of employment is $\frac{\hat{E}}{\hat{Y}}$. 
labour productivity. This pattern differs sharply from the pattern exhibited by the Asian economies, as productivity accounted for $96 \%$ of GDP growth and employment for just $4 \%$ in China, while the contributions of these two factors amounted to $80 \%$ and $20 \%$, respectively, in India, $70 \%$ and $30 \%$ in Japan, and 66\% and 34\% in the Republic of Korea. The differentials between these two factors are smaller in Europe and the United States but in both of those cases the contribution made by labour productivity is greater than it is in the region ( $46 \%$ and $64 \%$, respectively).

Figure 8

The Latin American and Caribbean region and other regions and countries: the contribution of employment and labour productivity to GDP growth, 2000-2019 averages

(Percentages)

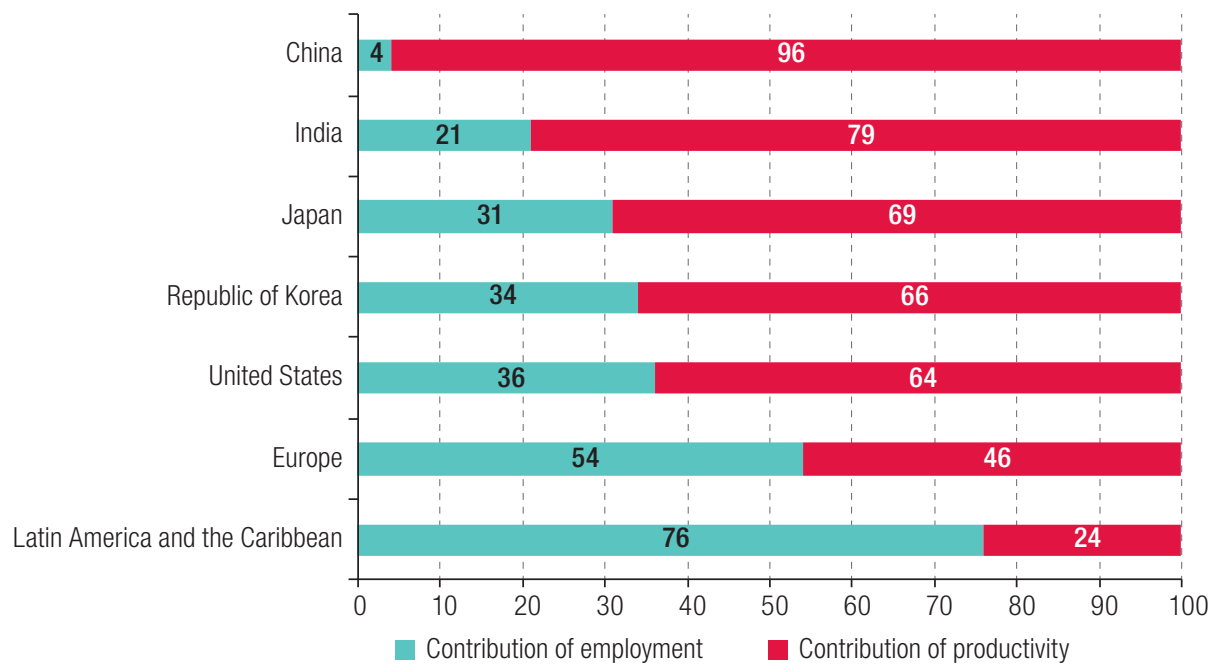

Source: Economic Commission for Latin America and the Caribbean (ECLAC), Building a New Future: Transformative Recovery with Equality and Sustainability (LC/SES.38/3-P/Rev.1), Santiago, 2020.

These results can be accounted for by the differing intensity of the technological effort made in these individual economies, and this is reflected with particular clarity in the trend in the ratio of R\&D to GDP. The reversion to a more commodity-based export mix in Latin America and the Caribbean during the commodity boom phase of the business cycle, combined with the weakness of the institutional framework for industrial policy in the region, has clearly militated against the development of a process of structural change that would increase the contribution of labour productivity to economic growth by improving the conditions for authentic competitiveness in the region's economies.

\section{Learning patterns in the presence of backward paths and hysteresis}

In their theoretical and empirical analysis of the persistently high unemployment levels found in the economies of Western Europe starting in the 1980s, Blanchard and Summers (1986) characterized this situation as the outcome of a process of "unemployment hysteresis" whereby a short-term increase in unemployment rates brought about by a recessionary shock may then be prolonged and eventually turn into a structural form of unemployment. According to Setterfield (2009), hysteresis is a special kind of path dependency in which the effects of a past shock on a variable $\mu$-for example, the rate of unemployment in a given economy - may influence the present value of that variable; put another 
way: $\mu_{t}=f\left(\mu_{t-1}\right)$ and $f^{\prime}\left(\mu_{t-1}\right)>0$, that is, that the present rate of unemployment depends on its previous values and that an increase in those values generates an increase in their present value. ${ }^{4}$

A pivotal factor in this analysis is the determination of whether or not, in the aftermath of a past unemployment shock (as a consequence of a global economic crisis, for instance), unemployment then follows a process akin to a random walk (the dynamic exhibits a unit root). This is tantamount to maintaining that the unemployment shock is permanent or extremely long-lasting, or that it is stationary with drift. Not all of the econometric evidence for the world at large or for the region in particular points in the same direction, but it is clear that, in the wake of the North Atlantic crisis of 2008-2011, unemployment trends in some developed economies and in Latin America suggest that a process of hysteresis is at work.

Figure 9 provides a comparison of the creation of value added and labour productivity in China, the United States and Latin America. The curves for the Chinese and United States economies indicate that when increases in value added are coupled with increases in labour productivity, employment levels also rise. Especially in China's case, the confluence of steady increases in productivity and in employment has driven up GDP. In Latin America, this interaction has been much weaker. After 2009, GDP climbed while productivity slipped (suggesting that output was raised by increasing lower-productivity forms of employment) and, starting in 2014, both productivity and employment -and, along with them, GDP - began to fall.

Figure 9

Latin America, United States and China: labour productivity and value added (Dollars and billions of dollars)

A. Latin America, 1990-2019

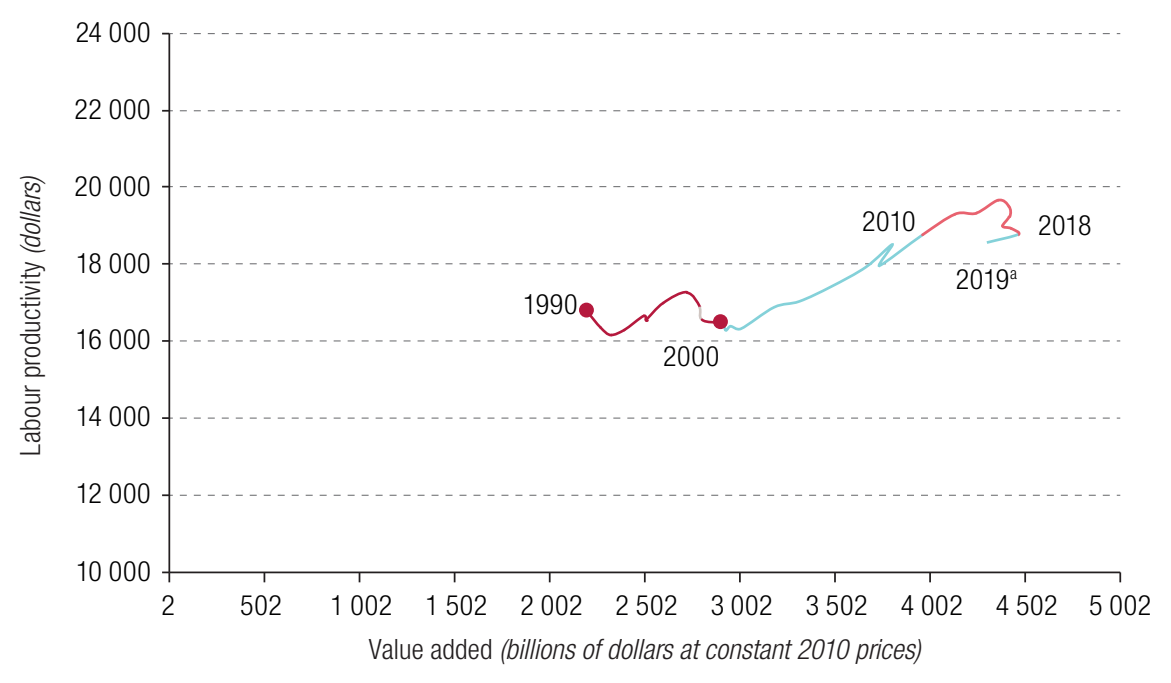

4 The concept of hysteresis describes a situation in which an economy's parameters are altered by a shock in such a way that the economy cannot revert to its original state even after the shock wanes. Consequently, periods in which a currency appreciates sharply or unemployment rises steeply may have a long-lasting effect rather than simply generating short-run fluctuations. 
Figure 9 (concluded)

B. United States, 1990-2018
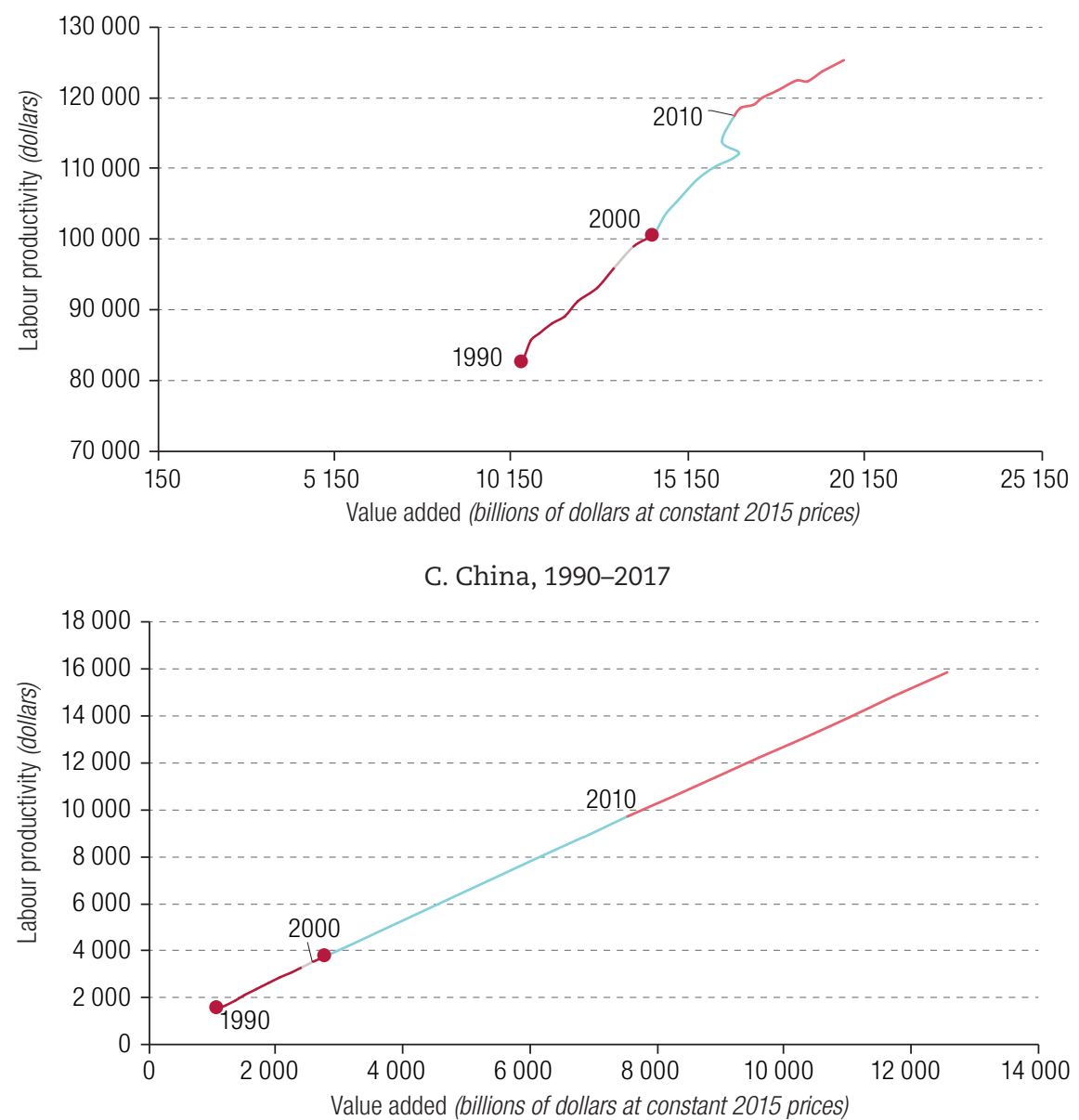

Source: Prepared by the author on the basis of statistics provided by Economic Commission for Latin America and the Caribbean (ECLAC); System of National Accounts of the United Nations; ECLAC/ International Labour Organization (ILO), "Work in times of pandemic: the challenges of the coronavirus disease (COVID-19))", Employment Situation in Latin America and the Caribbean, No. 22 (LC/TS.2020/46), Santiago, July 2020.

a Figures for 2019 are estimates.

\section{Secular deterioration in factor income distribution}

A stylized fact of global capitalism over the last 70 years is that factor income distribution has been deteriorating in a way that works to the detriment of labour (Torres, 2019). This has been a cross-cutting trend encompassing both developed countries and developing economies. Since the 1950s - when developmentalism was in full swing - and until the recent period of hyperglobalization, the share of wages in GDP has been steadily shrinking in the Latin America economies and in those of the member States of the Organization for Economic Cooperation and Development (OECD). In Latin America, the share of wages slipped from $41 \%$ in 1950 to $35 \%$ in 2014, while in the OECD countries it fell from 65\% to less than 59\% during that same period (see figure 10). As of 2014 -the most recent year for which information is available - this long-standing decline in the share of wages was the net effect of some sharply contrasting shifts in both the OECD and the Latin American economies, however. ${ }^{5}$

\footnotetext{
5 For an analysis of the cases of 15 Latin American countries, see Alarco (2014) and, for information on the member States of the Organization for Economic Cooperation and Development (OECD), see the Penn World Table database [online] at: https:// www.rug.nl/ggdc/productivity/pwt/.
} 
Figure 10

Latin America and the Organization for Economic Cooperation and Development (OECD): trends in the share of wages in GDP, 1950-2014

(Percentages)

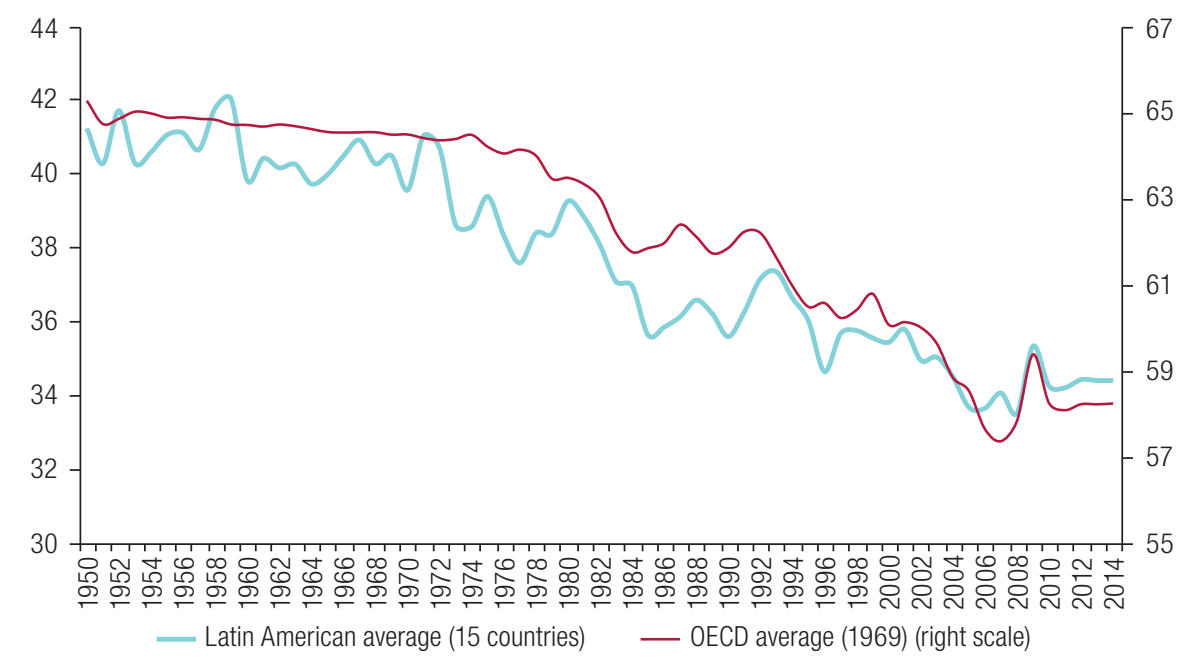

Source: Economic Commission for Latin America and the Caribbean (ECLAC), "Wage share and economic growth in Latin America, 1950-2011", CEPAL Review, No. 113 (LC/G.2614-P), Santiago, Economic Commission for Latin America and the Caribbean (ECLAC), 2014 and University of Groningen, Penn World Table [online database] https://www.rug.nl/ggdc/ productivity/pwt/.

For example, the share of wages in countries such as Belgium, Canada, Denmark, Finland and France is over $60 \%$, whereas, in the economies in which the share of wages in GDP is the smallest (Italy, Japan and the United Kingdom), the figure ranges from 43\% to 48\%. In Latin America, Costa Rica is the country where wages account for the largest share, at $50 \%$, followed by Brazil and Honduras, where the corresponding figure is around $45 \%$. In contrast, the share of wages in GDP in the Bolivarian Republic of Venezuela, Peru and Mexico is between $20 \%$ and $29 \%$. To some extent, the values of this indicator in Latin America are reflecting structural problems in the region's labour markets, such as a lack of labour flexibility, domestic production gaps, the nature of the production sector's patterns of specialization and the workforce's weakened ability to unionize, to say nothing of these economies' high levels of informality. The asymmetrical nature of factor income distribution is a fundamental factor in the regressive nature of personal income distribution. Furthermore, it is reasonable to assume that, given the economic stagnation seen in 2014-2019 and the serious setbacks in terms of employment and wages caused by the health crisis, both of these distributions will deteriorate further in the future.

\section{A widening external gap}

Given this state of affairs, the Latin American and Caribbean region is not narrowing the external productivity gap separating it from the developed world. Figure 11 illustrates how, even though per capita GDP in both Latin America and the Caribbean has been on the rise relative to that of the OECD countries and the United States since 1990 (after the "lost decade" of the 1980s), it has not regained the levels of the period 1950-1989. And, in line with points made in the first part of this section, the gap in this indicator between the region and developed economies began to widen again in the 2010s. 
Figure 11

Latin America and the Caribbean: divergence in production expressed as per capita GDP of the region as a percentage of per capita GDP of the Organization for Economic Cooperation and Development (OECD) and the United States, 1900-2018

\section{A. Gap with OECD economies ${ }^{a}$}

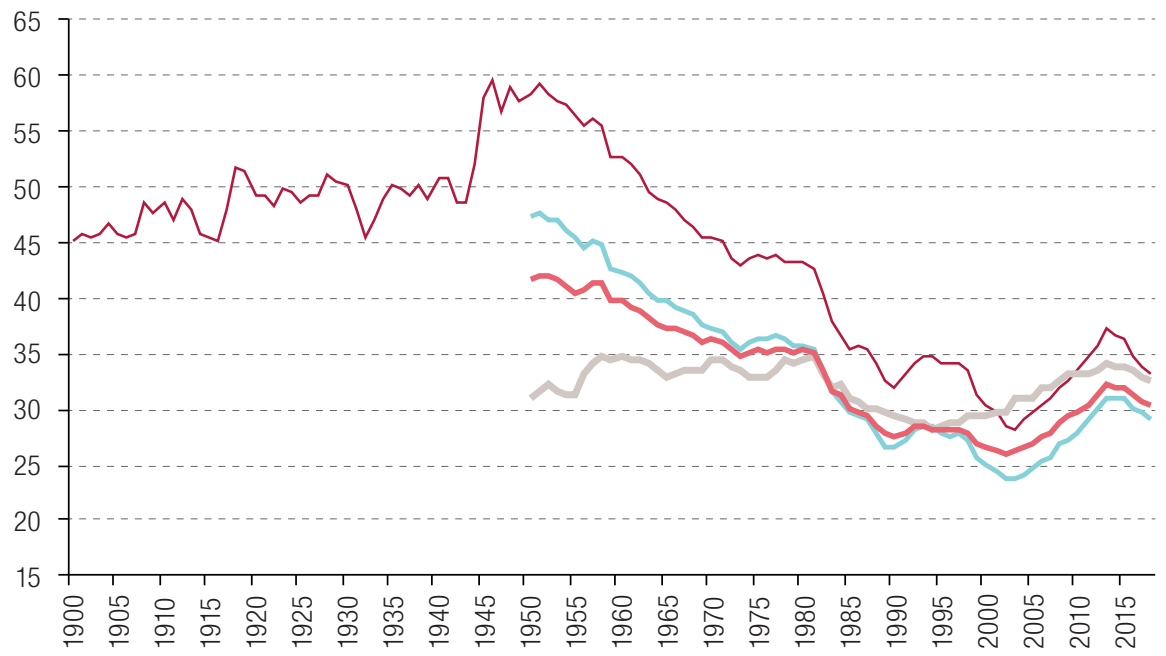

B. Gap with United States

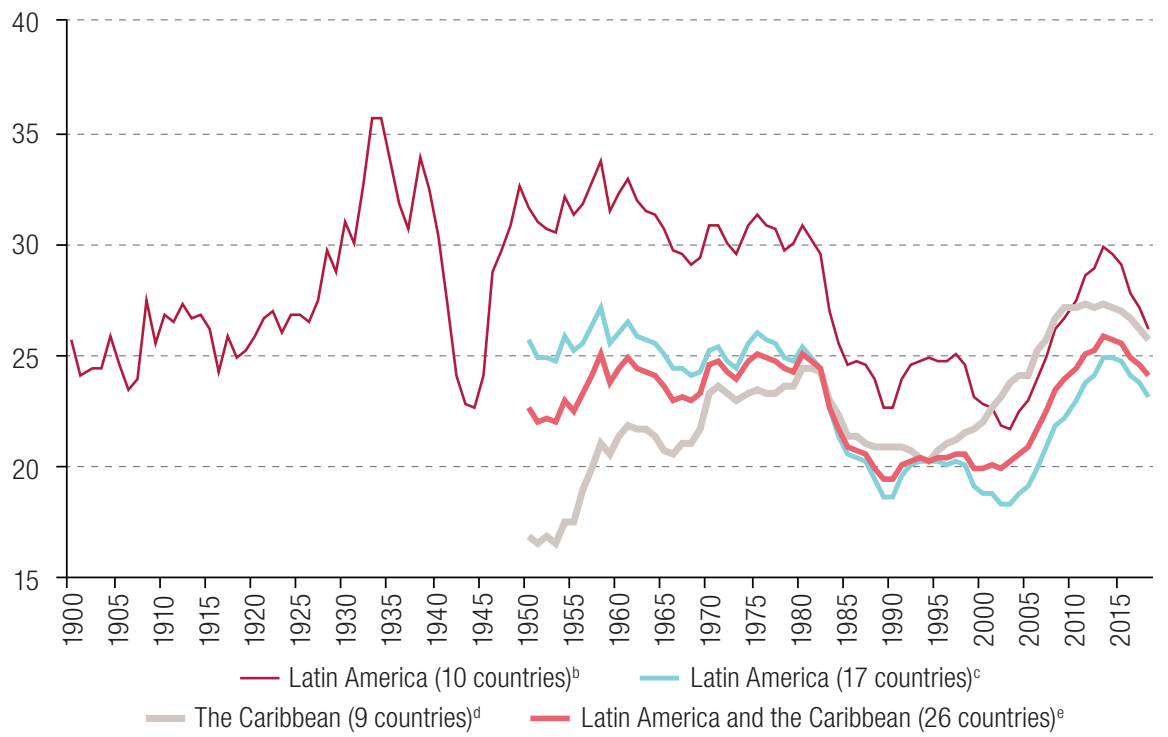

Source: University of Groningen, Penn World Table [online database] https://www.rug.nl/ggdc/productivity/pwt/.

a The gap with OECD was calculated using data for 20 countries for the period 1900-1949 and using data for 24 countries (member countries up to 1973) from 1950 on.

b Argentina, Bolivarian Republic of Venezuela, Brazil, Chile, Colombia, Ecuador, Mexico, Peru, Plurinational State of Bolivia and Uruguay.

c Argentina, Bolivarian Republic of Venezuela, Brazil, Chile, Colombia, Costa Rica, Ecuador, El Salvador, Guatemala, Honduras, Mexico, Nicaragua, Panama, Paraguay, Peru, Plurinational State of Bolivia and Uruguay.

d Barbados, Cuba, Dominica, Dominican Republic, Haiti, Jamaica, Puerto Rico, Saint Lucia, and Trinidad and Tobago.

e Argentina, Barbados, Bolivarian Republic of Venezuela, Brazil, Chile, Colombia, Costa Rica, Cuba, Dominica, Dominican Republic, Ecuador, El Salvador, Guatemala, Haiti, Honduras, Jamaica, Mexico, Nicaragua, Panama, Paraguay, Peru, Plurinational State of Bolivia, Puerto Rico, Saint Lucia, Trinidad and Tobago and Uruguay. 


\section{The three gaps}

As discussed in the previous section, the pandemic's impact on the region is framed by three structural crises: a social crisis that is reflected in high levels of inequality; an economic crisis that is reflected in low growth and a technological lag relative to advanced countries and (increasingly) some Asian economies; and an environmental crisis that is reflected in the loss of biodiversity, forests and water resources and in an upward trend in greenhouse gas emissions. As these three crises and the policies required to overcome them all interact with one another, an effort to change the region's development style will have to be based on a coordinated approach to all three of them. ECLAC (2020i) has proposed an integrated three-gap model for addressing the interactions among the relevant variables and the corresponding policy tools. This model is constructed on the basis of the three different growth rates that will be outlined here.

\section{A growth rate consistent with the maintenance of external equilibrium $\left(y^{\mathrm{E}}\right)$}

The first of these rates is a growth rate that is compatible with a basic component of the balance of payments (current account plus long-term capital movements) that is in equilibrium. For the sake of simplicity, the equation for a balanced trade growth model known as Thirlwall's law, as discussed in the second part of section III, can be used to describe this type of externally constrained growth:

$$
y^{E}=\frac{\varepsilon y^{C}}{\pi}
$$

In this expression, $y^{E}$ is the growth rate of the periphery for which the net trade balance is zero. ${ }^{6}$ Equation (1) defines the external equilibrium curve $E E$ (shown in diagram 1), which represents all combinations of $y^{E}$ and $y^{C}$ that satisfy balanced trade.

\section{The minimum rate required to reduce inequality $\left(y^{S}\right)$}

This is the rate required, on the one hand, to reduce structural heterogeneity by placing unemployed and underemployed workers in formal sector jobs in which productivity is on the rise and, on the other, to finance social policies and policies for transferring income from the highest-income deciles to the lowest-income deciles. While a great deal of the necessary reduction in inequality can be achieved by means of purely redistributive policies, formal sector job creation - made possible by growth and by the diversification of production - is a necessary complement to those policies.

\section{The maximum rate compatible with environmental constraints $\left(y^{A}\right)$}

This is the highest rate that is compatible with respect for the Earth and the protection of our planet for the enjoyment of future generations. From an operational standpoint, it can be measured in terms of greenhouse gas reduction targets, although conceptually it should be consistent with the necessary limitation of a variety of the environmental impacts of human activity, rather than solely climate change. This rate falls as the centre grows because that growth leaves less room for emissions from the periphery, since the total carbon budget must be shared by the two types of regions. The centre-periphery environmental frontier represents all possible combinations of growth in the periphery and the centre

6 For further information, see Blecker and Setterfield (2019), chapter 9. 
that are compatible with the existing carbon budget given the decarbonization rate associated with environmental innovations and their diffusion in the global economic system. Technical progress towards the decarbonization of production will reduce emissions per unit of GDP and boost $y^{A}$ relative to each increment of the centre's growth rate. As cleaner energy sources are used and as energy efficiency increases, the same carbon budget will become compatible with more growth.

\section{The interaction of the three rates}

The $y^{A}$ rate is the point at the crossover of two dimensions of inequality: (i) intergenerational inequality, based on the idea that future generations have the right to have access to the same environmental services for their development as current generations do; and (ii) intragenerational inequality, based on the idea that the poorer countries (and the poorest people in each country) have the right to raise their levels of income and well-being more quickly that the richer countries (and the richest people in each country) do.

Diagram 2 plots the following three gaps based on the assumption that the centre's growth rate is exogenous $\bar{y}^{C}$ : the social gap, which is the difference between the growth rate required to support equality and the rate that is compatible with an external equilibrium (the difference between $y^{S}$ and $y^{E}$, segment $\mathrm{A}-\mathrm{B}$ ); the environmental gap, which is the difference between the external equilibrium rate and the sustainability frontier (the difference between $y^{E}$ and $y^{A}$, segment B-C); and the sustainability gap, which is the difference between the equality growth rate and the environmental balance rate (the difference between $y^{S}$ and $y^{E}$, segment A-C).

\section{Diagram 1}

The three sustainable development gaps

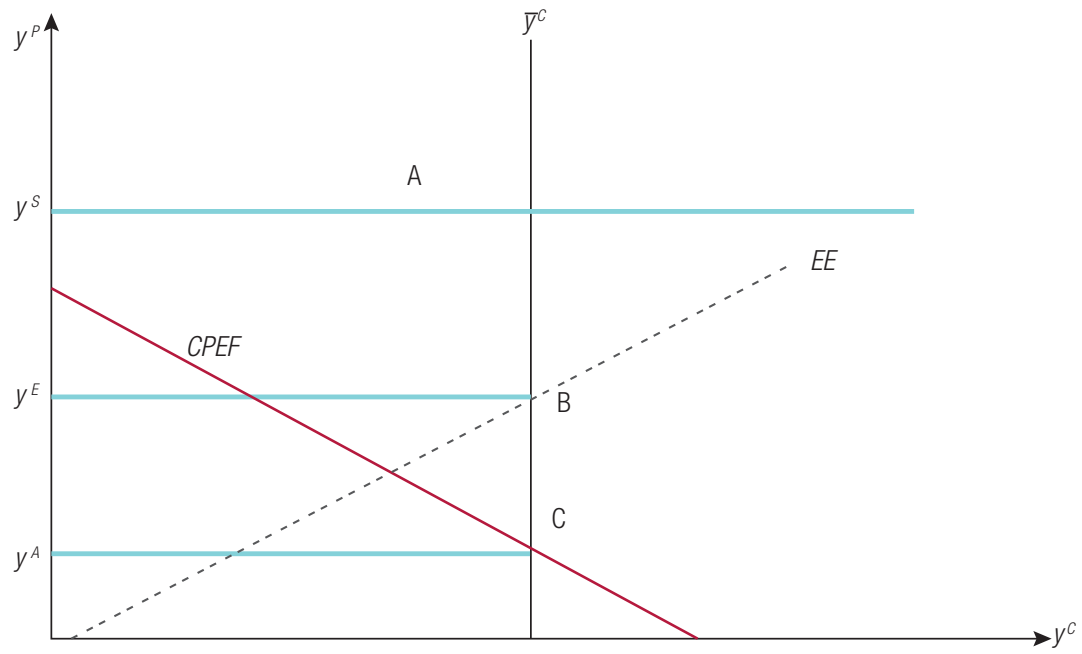

Source: Economic Commission for Latin America and the Caribbean (ECLAC).

Note:

$y^{P}$ : growth rate of the periphery.

$y^{C}$ : growth rate of the centre (exogenous and equal to $\bar{y}$ ).

$y^{E}$ : growth rate of the periphery that is compatible with the external constraint, which increases as the growth (and demand for imports) of the centre does and as the periphery's technological capacities do (authentic competitiveness).

$y^{S}$ : minimum growth rate for equality; the greater the initial level of inequality and the less of a redistributive effort that the country makes, the higher this rate will be.

$y^{A}$ : maximum growth rate for the periphery that is compatible with a global environmental balance, which falls as the centre grows and climbs with an increase in technical progress, particularly progress in the innovation and diffusion of environmental technologies.

Social gap: the distance between points $A$ and $B$.

Environmental gap: the distance between points B and C.

Sustainability gap (three dimensions): the distance between points $\mathrm{A}$ and $\mathrm{C}$.

$E E$ : growth rate of the periphery that is compatible with external equilibrium.

$C P E F$ : centre-periphery environmental frontier. 
Sustainable development, broadly defined, is achieved only when $y^{E}=y^{S}=y^{A}$, that is, when all three (social, economic and environmental) dimensions of the required sustainability conditions are fulfilled. ECLAC estimates (2020) for Latin America and the Caribbean indicate that: $y^{S}>y^{E}>y^{A}$.

Of the three rates, the one that tends to prevail in an open economy is the growth rate that is compatible with external equilibrium, as growth in excess of that rate requires taking on debt, and there is a limit to how much borrowing a country can finance on international markets. As a function of external pressures, the economy will move towards $y^{E}$. To achieve a sustainable form of development, a policy package is needed that will set the stage for the convergence of these rates. This kind of package can act as a driver of sustainability by raising investment levels in the various sectors of the economy on a coordinated basis so that sweeping social, productive and technological changes will reinforce one another. The rate on which the economy needs to converge is the equality growth rate, which is the highest of the three; thus, social, technological and environmental policies need to merge at level $y^{S}$.

On the one hand, social policies can lower the minimum rate required to support equality. This rate will be lower if the initial degree of inequality is low and if redistributive policies are ambitious ones. Growth and an increase in formal sector employment will invariably be essential mechanisms for reducing inequality, but they will be relatively less important (at least in the short run) in a welfare state.

On the other hand, industrial and technological policies can further the diffusion of technology and structural change in the periphery that will promote authentic competitiveness (and, along with it, the $\varepsilon / \pi$ ratio and external equilibrium growth rate, $y^{E}$,) (see Cimoli and Porcile, 2014; Cimoli, Pereima and Porcile, 2019).

Finally, in order for $y^{E}$ and $y^{A}$ to converge, technical progress must move in certain prescribed directions, i.e. towards raising the efficiency of energy use, reducing greenhouse gas emissions and promoting sustainable forms of production. Innovation and technology diffusion policies should not only bolster authentic competitiveness but also steer the economy towards low-carbon development paths based on the use of renewable energy.

In order for this approach to be viable, cross-policy complementarities need to be explored. Policies for promoting investment in renewable energy sources can lower the cost of energy and, in so doing, support international competitiveness; policies for supporting education and encouraging people to adopt sustainable consumption patterns will help to ensure that environmental innovations are also supportive of competitiveness (since the goods being offered will fit in with emerging demand patterns); industrial policies that spur the domestic production of electric vehicles or vehicle parts will reduce external deficits and emissions; social policies aimed at achieving universal health care and education will contribute not only to equality but also to productivity, technological learning and competitiveness. Diagram 2 provides an overview of cross-policy complementarities and illustrates the need for their coordination in order to build momentum for a major effort in this regard.

The minimum growth rate for equality could be lowered from $y^{S 1}$ to $y^{S 2}$ (from point A to point B) by means of more extensive social and welfare policies. At the same time, industrial and technology policies could be pushing up the centre-periphery environmental frontier and the rate that would be compatible with protection of the environment (from point $\mathrm{C}$ to point $\mathrm{B}$ ) by, among other things, promoting investment in renewable energy or sustainable forms of farming and tourism. Technological and structural changes can alter curve $\mathrm{EE}$ (whose slope is given by $\varepsilon / \pi$ ), shifting the external equilibrium growth rate from point $A$ (initial position) to point $B$ (following a change in the pattern of specialization). It is essential for these policy tools to be brought to bear on these three curves in a carefully coordinated manner. 


\section{Diagram 2}

Policies that promote both equality and technical progress

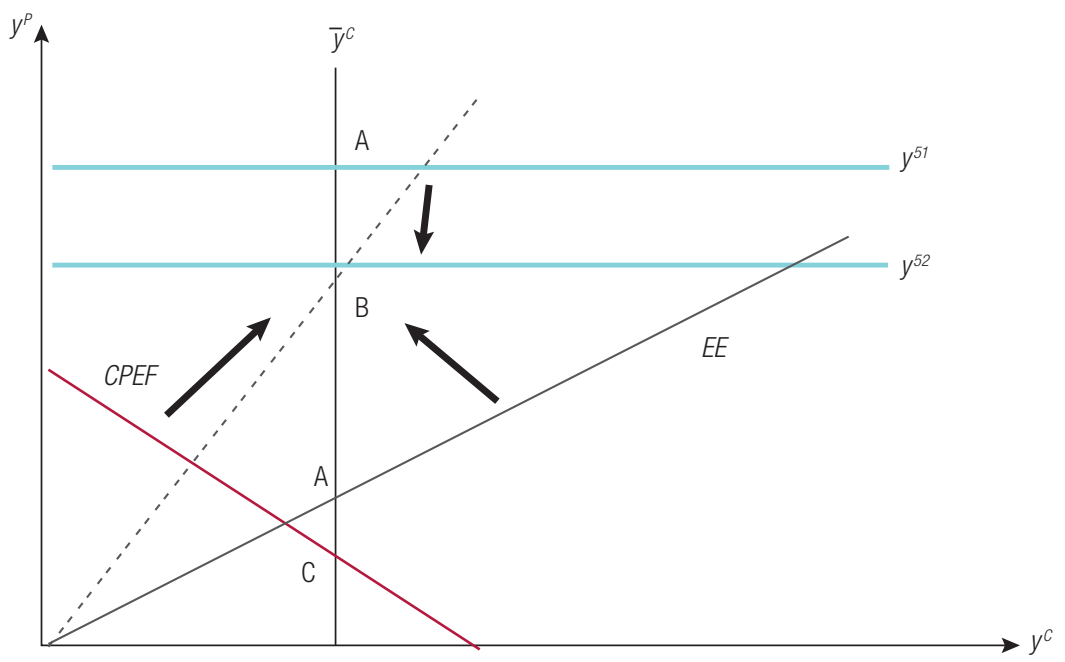

Source: Economic Commission for Latin America and the Caribbean (ECLAC).

Note:

$y^{P}$ : growth rate of the periphery.

$y^{C}$ : growth rate of the centre (exogenous and equal to $\bar{y}^{C}$ ).

$y^{S}$ : minimum growth rate for equality; the greater the initial level of inequality and the less of a redistributive effort that the country makes, the higher this rate will be.

Social gap: the distance between points A and B.

Environmental gap: the distance between points B and C.

Sustainability gap (three dimensions): the distance between points $\mathrm{A}$ and $\mathrm{C}$.

$E E$ : growth rate of the periphery that is compatible with external equilibrium.

$C P E F$ : centre-periphery environmental frontier.

\section{Economic and social impacts during the pandemic}

The pandemic has had a huge impact on aggregate supply and demand in the region. The intensity and persistence of these effects will be directly related to the conditions existing within each economy, as well as global trade dynamics, the duration of the health crisis, and the health, economic and social policies adopted to mitigate those effects.

ECLAC (2020a) has classified the costs of the pandemic according to its direct effects on the region's health-care systems and its indirect effects on production and consumption. The direct effects include the greater pressure being exerted on the region's highly fragmented health-care facilities, which will heighten the pre-existing inequality in access to health-care services for people of different income levels and areas of residence. The indirect effects on aggregate supply and demand stem from the fact that lockdowns and social distancing requirements have led to the suspension of production activities in the areas of education, commerce, tourism, transport and natural resource development. 


\section{Economic impacts ${ }^{7}$}

\section{(a) The macroeconomic scale of the crisis}

In the short run, the crisis is expected to lead to higher unemployment, lower wages and income levels, and increased poverty, extreme poverty and inequality. In the medium and long terms, its greatest repercussions are likely to be the bankruptcy of numerous businesses, a downturn in private investment, a decline in growth rates, a reduction in the degree of integration of global value chains and a deterioration in production capacity and human capital. ECLAC has argued that the reactivation of the region's economy calls for an appropriate contextualization and understanding of the true proportions of these effects. In fact, when the crisis triggered by the COVID-19 pandemic is viewed within its historical context, it becomes clear, as ECLAC (2020b and 2020h) has pointed out, that this is the most severe crisis to be experienced since the years following the Second World War (see figure 12).

Figure 12

Latin America and the Caribbean: real GDP growth rates, 1951-2019

(Percentages)

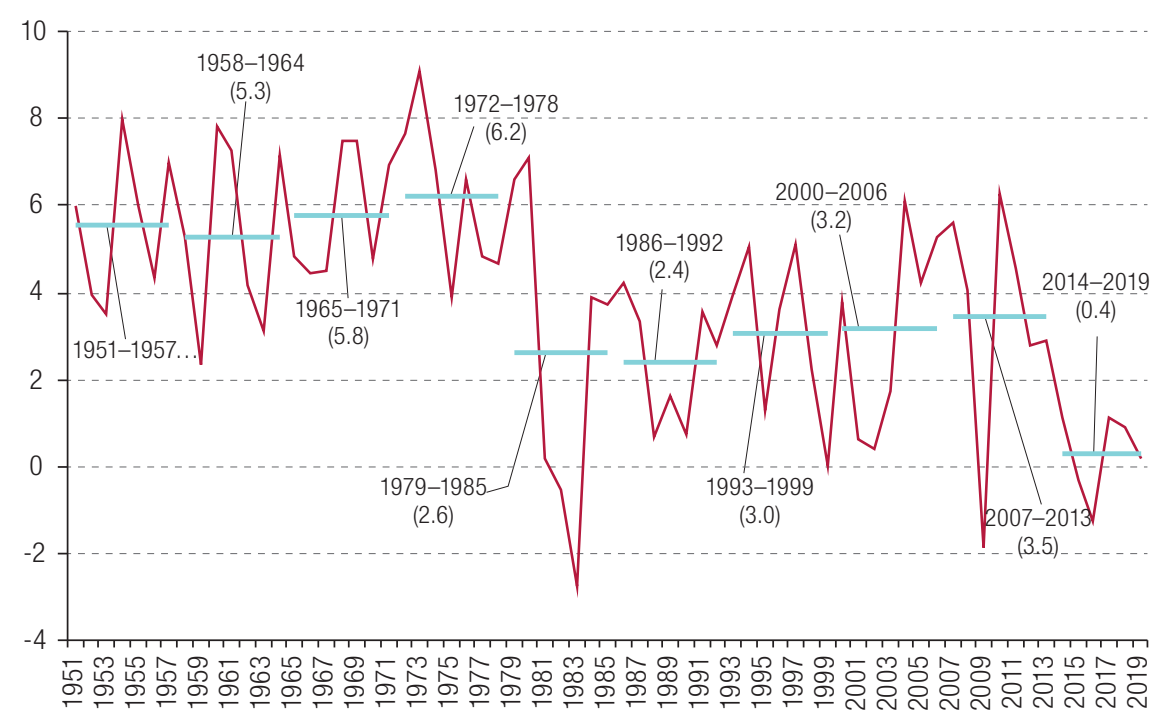

Source: Economic Commission for Latin America and the Caribbean (ECLAC), on the basis of official figures.

ECLAC has calculated that the region's per capita GDP will shrink by $8.5 \%$, thus falling back to around 2010 levels. This means that the end result of the pandemic and the recessionary period that preceded it will be another "lost decade".

As this stark retrogression takes hold, the productive fabric will thin out and the region's already problematic structural heterogeneity will be amplified. In more concrete terms, it is estimated that the pandemic will force the closure of some 2.7 million formal sector businesses in the region (ECLAC, 2020d) and that 44 million people will be unemployed, or 18 million more than in 2019. This will be the biggest jump in joblessness since the global financial crisis, when the unemployment rate climbed from $6.7 \%$ in 2008 to $7.3 \%$ in 2009. According to the indicators shown in table 4, the year-on-year unemployment rate will reach $13.5 \%$ of the economically active population (EAP) (ECLAC, 2020e and 2020h).

\footnotetext{
7 For a complementary analysis of this topic, see Bárcena (2020).
} 
Table 4

Latin America and the Caribbean: employment indicators, 2020a

(Millions of persons and percentages)

\begin{tabular}{lc}
\hline Indicator & 2020 \\
\hline Economically active population (EAP) & 326.9 \\
\hline Number of unemployed & 44.1 \\
\hline Change in number of unemployed & 18.0 \\
\hline Unemployment rate (percentage) & 13.5 \\
\hline
\end{tabular}

Source: Economic Commission for Latin America and the Caribbean (ECLAC), on the basis of official figures.

a Projections.

As for the adverse effects of the crisis on aggregate demand, ECLAC (2020h) projects that the contractions in all of the main components (investment, consumption and exports) will overshadow those observed during the international financial crisis of 2008 and 2009. While real investment fell by $11.2 \%$ in 2009 , it is estimated that it will have plunged by $20.4 \%$ in 2020 . Projections also indicate that consumption will have diminished by $9.5 \%$ in 2020 (compared to a contraction of just $0.2 \%$ during the earlier crisis) and that exports will be down by $11.5 \%$ (compared to a drop of $9.1 \%$ in 2008-2009) (see figure 13).

Figure 13

Latin America and the Caribbean: year-on-year variation in the components of aggregate demand, 2008-2009 and 2019-2020

(Percentages)

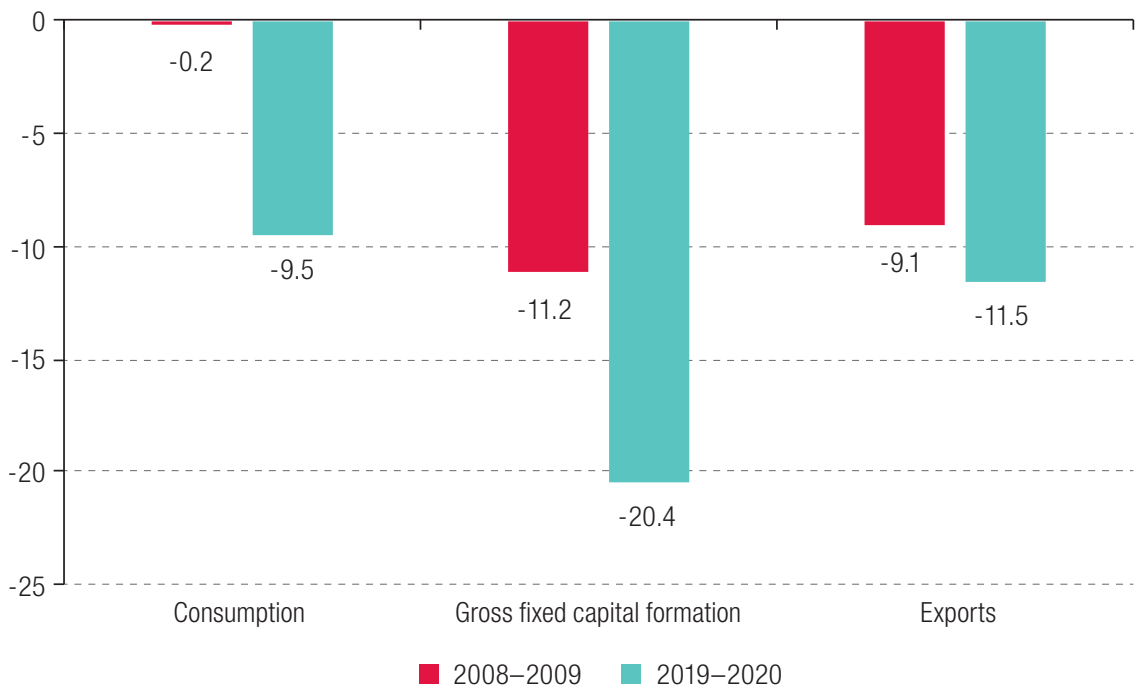

Source: Economic Commission for Latin America and the Caribbean (ECLAC), on the basis of official figures.

a Projections.

\section{(b) Impact of the crisis on regional trade}

As noted earlier, the contraction of the region's GDP is associated with the external effects of the pandemic on international trade and the widespread decline in the prices of the region's commodity exports. As ECLAC (2020f) has observed, "The COVID-19 outbreak occurred in a context of sluggish global trade that has been dragging on since the 2008-2009 financial crisis". ECLAC estimates that, between January and May 2020, the value of the region's exports and imports of goods was down by $17 \%$ from its level during the same period in 2019. Both exports and imports plummeted towards the end of this five-month period, registering year-on-year drops of $37 \%$ in May. 
The year-on-year reduction in the volume of trade in April-May 2020 (a drop of 20\% for exports and one of $25 \%$ for imports) was much sharper than it had been in the corresponding period of 2009 (see figure 14). The downturn in exports is attributable to both the supply shock generated by the partial shutdown of production activities and the demand shock sparked by the economic downswing in the main markets for the region's exports. In the case of imports, the contraction is mainly a result of the deep recession that has overtaken the region, where output is expected to shrink by $9.1 \%$ (ECLAC, 2020e).

Figure 14

Latin America and the Caribbean: year-on-year variation in exports and imports of goods, by volume, price and value, January 2007 to May 2020

(Percentages)

\section{A. Exports}

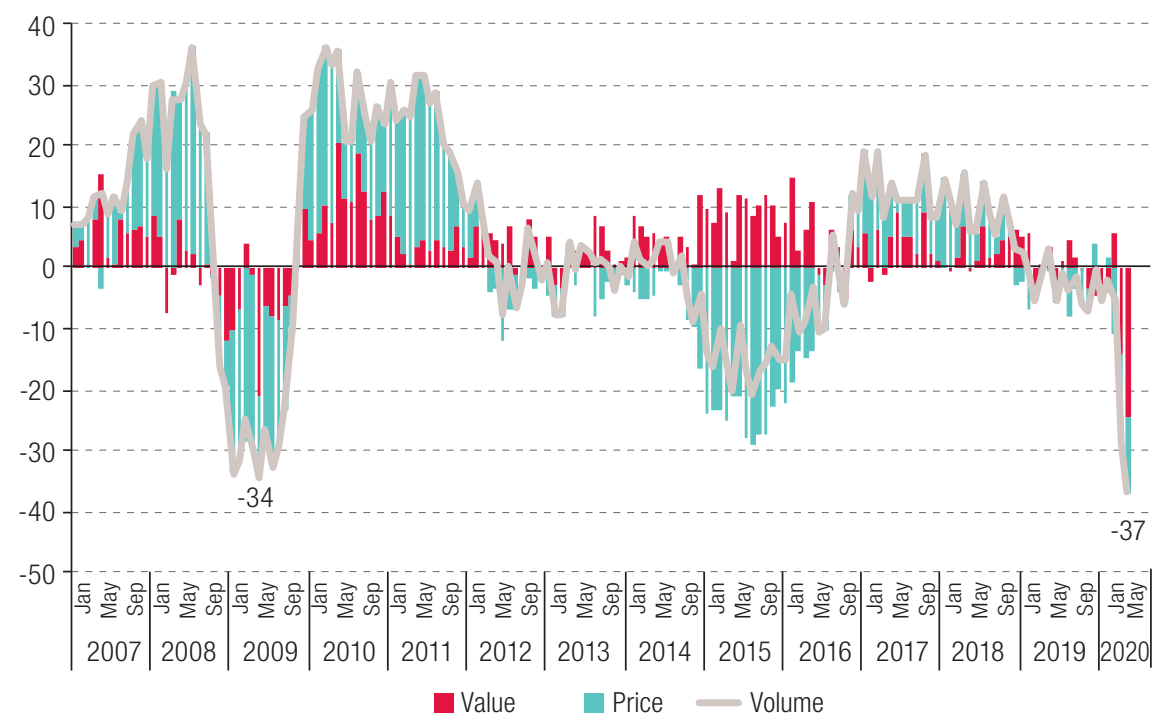

B. Imports

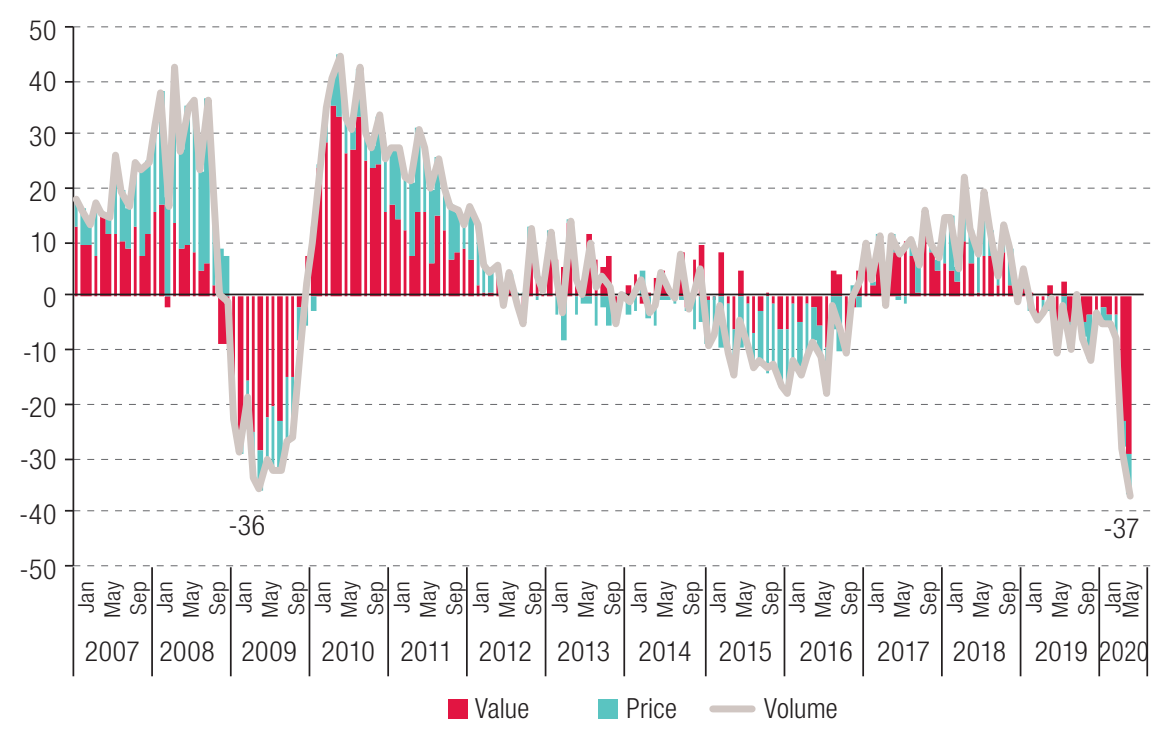

Source: Economic Commission for Latin America and the Caribbean (ECLAC), on the basis of information from the countries' central banks, customs services and statistical offices. 


\section{(c) Effects of the crisis on productive development and entrepreneurship}

ECLAC (2020d) has classified the different branches of production activity, based on the strength of the crisis' impact on output and employment, as follows: (i) heavily affected sectors: tourism; traditional cultural industries; repair services; hotels and restaurants; transport; fashion; and motor vehicles; (ii) significantly affected sectors: mining; electricity, gas and water; construction and building materials; business services; financial activities; beverages; furniture and lumber; chemicals; and electronics, machinery and equipment; and (iii) moderately affected sectors: crop farming, stock raising and fisheries; food production for the domestic market; medical inputs and equipment; medicines; telecommunications; and packaging. On the basis of this classification, it is estimated that $34.2 \%$ of formal sector employment and $24.6 \%$ of the region's GDP correspond to sectors that are being heavily affected by the crisis; less than $20 \%$ of formal sector employment and GDP is being generated in moderately affected sectors, and $61.3 \%$ of GDP and $47.6 \%$ of formal sector employment are generated in sectors that are being affected to a significant extent (see figure 15).

Figure 15

Latin America and the Caribbean (27 countries): GDP and employment in different sectors, by strength of the expected impact of the crisis, 2020

(Percentages)

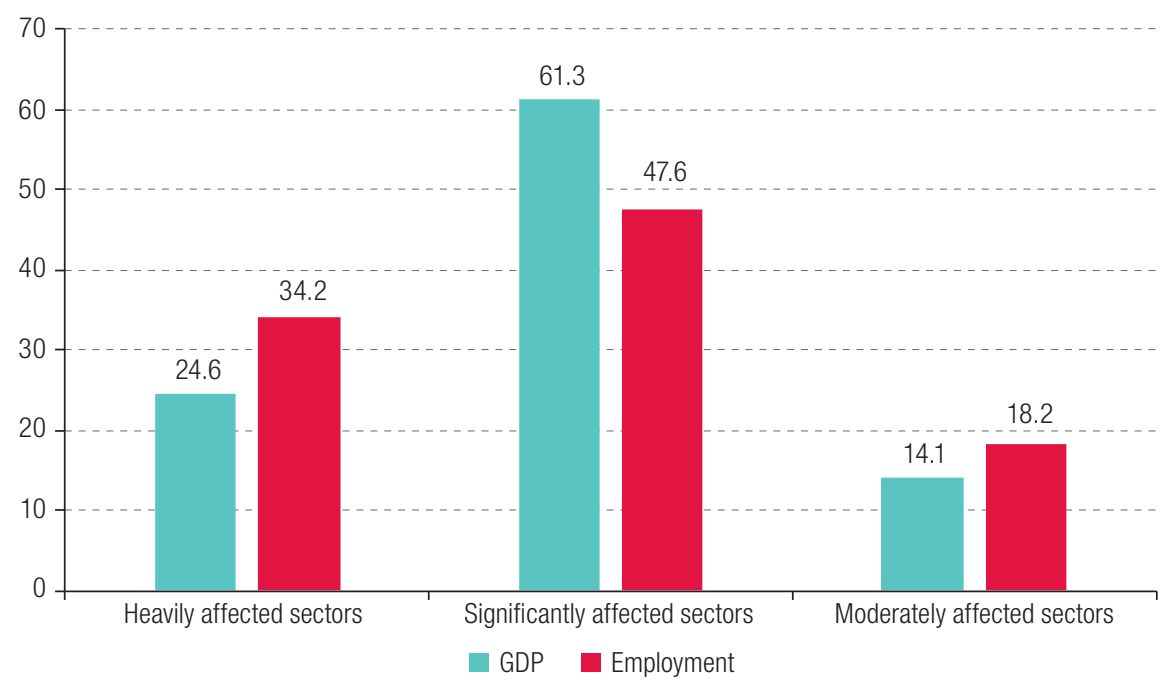

Source: Economic Commission for Latin America and the Caribbean (ECLAC), on the basis of official figures.

Out of all the businesses that will close their doors, the greatest impact is likely to be felt by micro-, small and medium-sized enterprises (MSMEs), given the share of production and employment that they account for. Studies conducted by various chambers of commerce in the region estimate that 2,650,528 microenterprises will go out of business because of the health crisis $(20.7 \%$ of the total), along with 98,708 small enterprises (7.1\%), 5,943 medium-sized business ventures (2.8\%) and 406 large companies (0.6\%) (ECLAC, 2020d). The job losses that will be caused by these closures are estimated at $6,383,958$ jobs (21.5\% of the total) in microenterprises, $1,512,655$ jobs $(7.3 \%)$ in small businesses, 390,155 jobs (2.7\%) in medium-sized ones and 231,724 jobs (0.6\%) in large companies.

Finally, as observed in an earlier study by ECLAC (2020g), the digital economy has partially offset the adverse effects seen in brick-and-mortar production and financial sectors. In fact, the solutions provided in the areas of health, education, commerce and employment by remote communications applications have played a pivotal role in the struggle to curb the health and economic impacts of the 
pandemic. That same study also sounds a warning, however, about the potential widening of the digital divide as the demand for broadband connections swells, since the social sectors that have the least access to these connections are lower-income groups, older age cohorts and residents of rural areas.

\section{Social effects}

The economic effects analysed in the preceding section will have social repercussions. The region is expected to lose some of the ground gained in the 2000s and 2010s in its bid to reduce poverty and inequality.

\section{(a) Poverty and extreme poverty}

As a consequence of the pandemic, poverty rates in the region will climb back to the levels seen some 15 years ago. ECLAC estimates based on the results of household surveys indicate that the size of the poor population in Latin America will be the same in 2020 as it was in 2005 (231 million people), and 96 million people will be below the extreme poverty line, which is comparable to the figure for 1990. In percentage terms, the poverty rate will climb by 7.0 percentage points relative to the 2019 rate, while the extreme poverty rate will be 4.4 percentage points higher (see figure 16).

\section{Figure 16}

Latin America (18 countries): poverty projections, 2019 and 2020

(Percentages)

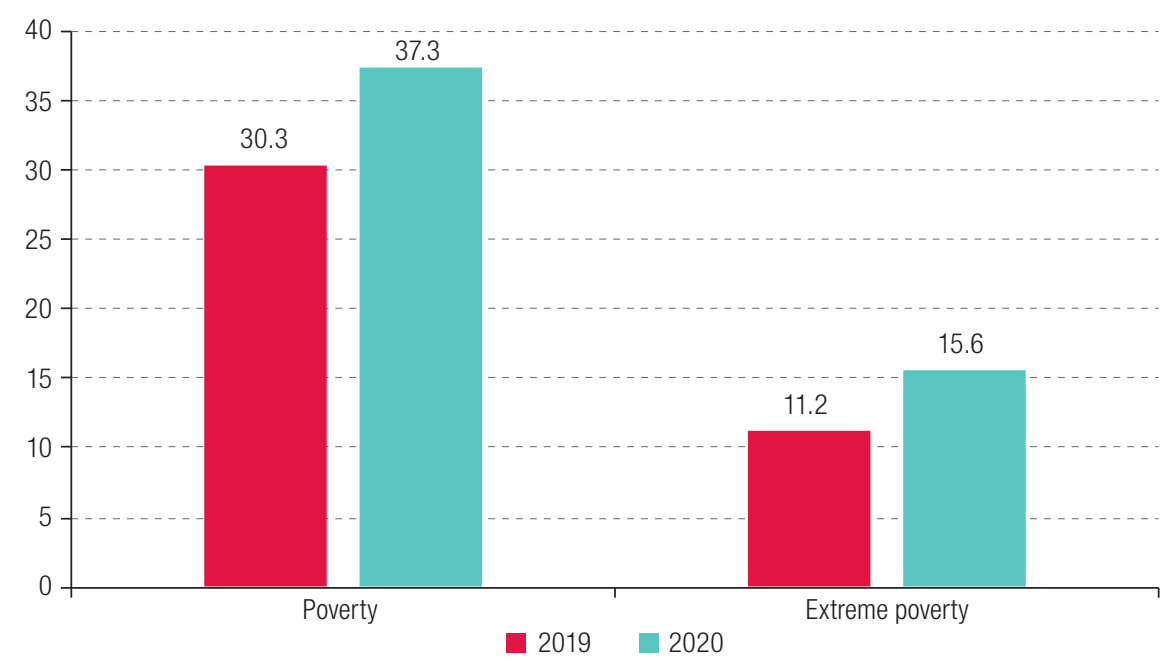

Source:Economic Commission for Latin America and the Caribbean (ECLAC), on the basis of Household Survey Data Bank (BADEHOG).

\section{(b) Effects on income distribution}

ECLAC (2020c) has projected that the job losses and wage cuts occasioned by the pandemic will lead to a reversal in all the countries of Latin America of some of the progress made in improving income distribution. Figure 17 illustrates the deterioration in income distribution in the region in 2014-2019 as compared to the situation during the commodity price boom of 2003-2014. During that boom period, rapid economic growth (especially in South America) enabled governments to boost social spending aimed at reducing poverty at the same time that companies were hiring more workers. The resulting shrinkage of the informal sector and increase in labour income translated into improvements in distribution 
which, although they were just a first step, nonetheless represented a significant advance for many countries. The end of the commodity boom in 2014 triggered an about-face in all these social and economic trends as the demand for raw materials waned and the production matrix rapidly reverted to an emphasis on primary sector activities. This had the effect of exacerbating the region's structural heterogeneity and rolling back distributive gains.

Figure 17

Latin America (17 countries): personal income distribution, 2003-2014 and 2014-2019 (Gini coefficient on a scale from 0 to 1 )

A. 2003-2014

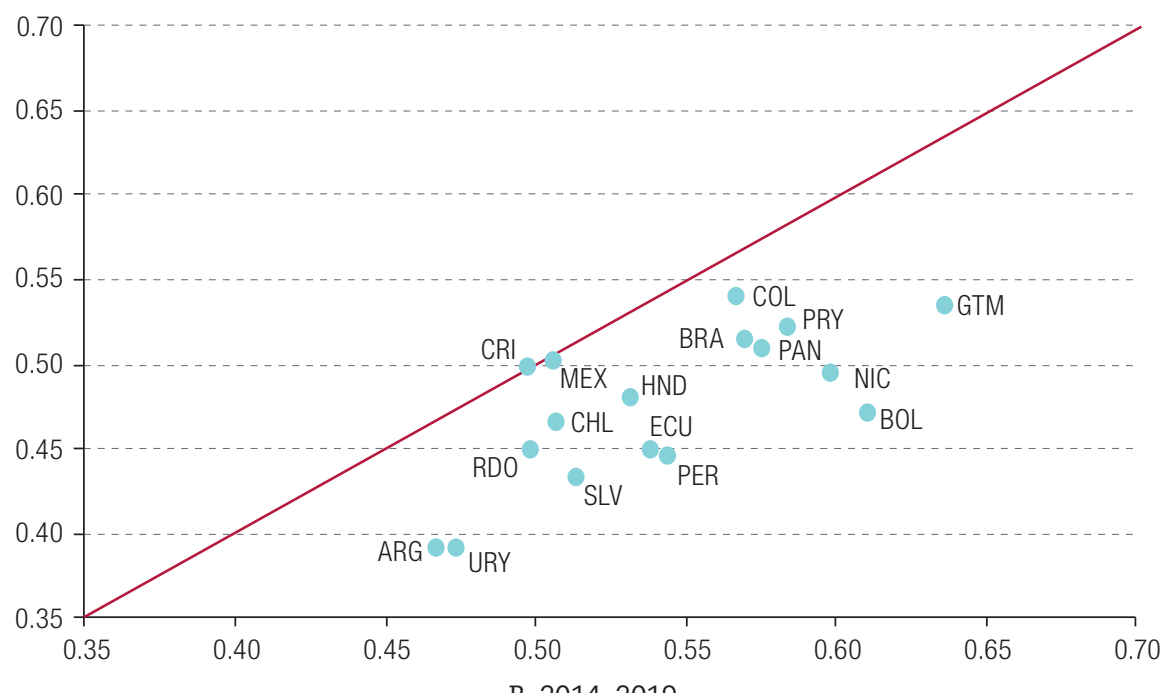

B. 2014-2019

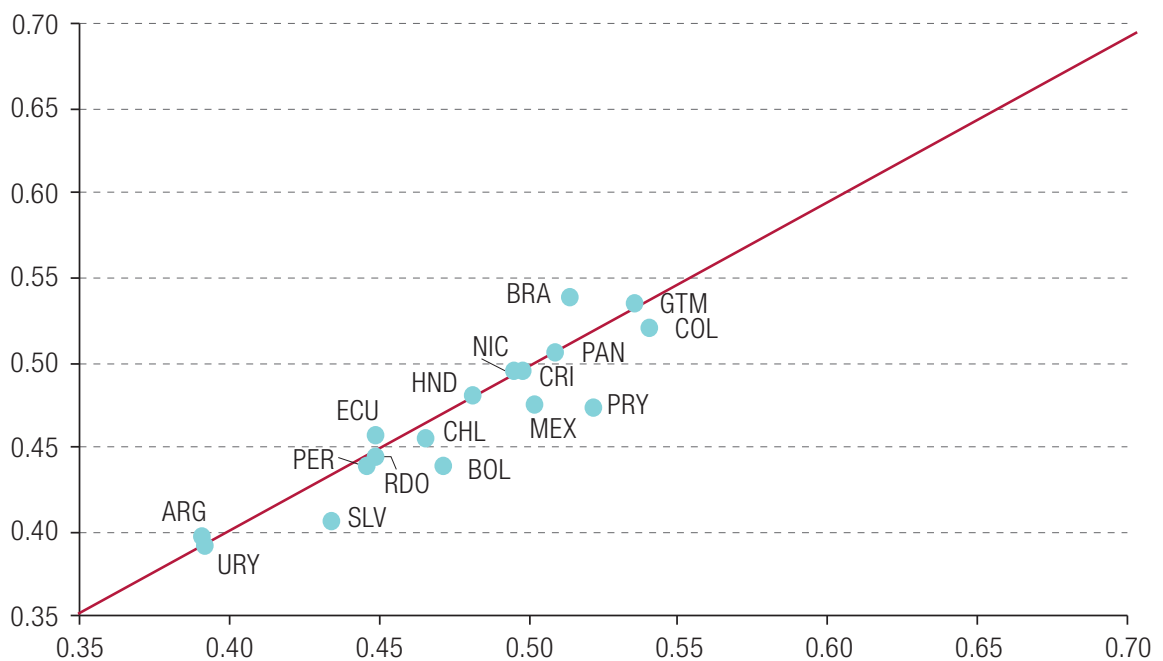

Source:Economic Commission for Latin America and the Caribbean (ECLAC), on the basis of Household Survey Data Bank (BADEHOG).

Table 5 shows the projected increases in the Gini coefficient for 2020, classified by percentage ranges. These increases, as observed earlier, will be widespread and will vary markedly from one country to another. Guatemala, Nicaragua and Paraguay will see their coefficients rise by between $1.0 \%$ and $2.9 \%$, while countries such as the Plurinational State of Bolivia, Costa Rica, Panama and the Dominican Republic will have increases of between $3.0 \%$ and $4.9 \%$. Most of the countries of the region, including Brazil, 
Chile, Colombia, El Salvador, Mexico and Uruguay, will experience even greater setbacks in income distribution, with their Gini coefficients jumping by between 5.0\% and 6.9\%. Argentina, Ecuador and Peru will lose the most ground of all in terms of distribution as their Gini coefficients will be over $7.0 \%$ higher.

Table 5

Latin America (17 countries): projected increases in the Gini coefficient in 2020 (Percentage ranges relative to 2019)

\begin{tabular}{cccc}
\hline $1.0 \%-2.9 \%$ & $3.0 \%-4.9 \%$ & $5.0 \%-6.9 \%$ & Over $7.0 \%$ \\
\hline Guatemala & Costa Rica & Brazil & Argentina \\
\hline Honduras & Dominican Republic & Chile & Ecuador \\
\hline Nicaragua & Panama & Colombia & Peru \\
\hline Paraguay & Plurinational State of Bolivia & El Salvador & \\
\hline & & Mexico & \\
\hline & Uruguay & \\
\hline
\end{tabular}

Source:Economic Commission for Latin America and the Caribbean (ECLAC), on the basis of Household Survey Data Bank (BADEHOG).

It is important to remember that the impacts of the health crisis will not be spread evenly over the various segments of the population. As pointed out by ECLAC: "The different socioeconomic impacts reflect the social inequality matrix in the region, which is built around the axes of socioeconomic stratum or social class, gender, life-cycle stage, ethnicity or race and territory, along with other factors such as disability, migratory status and homelessness. These inequalities accumulate, strengthen and interact, causing multiple forms of discrimination that lead to differences in the exercise of rights" (2020c, p. 5).

\section{Concluding observations: from the crisis to a new development pattern}

In this article we have analysed the situation in Latin America and the Caribbean in the light of the COVID-19 health crisis and have shown that it is the region in which the health and socioeconomic impacts of the pandemic have been the most severe. We have also shown that this outcome is directly related to the pre-pandemic situation in the region. The structural asymmetries that account for the intensity of the crisis in this region include its pattern of specialization, divergent trends in productivity and employment, and the deterioration in its functional distribution of income in conjunction with a range of more far-reaching inequalities.

This analysis of the pandemic's economic and social effects in the region underscores the enormous challenge to be met by the region if it is to deploy the macroeconomic, social and production policies needed to reactivate the economy once the crisis has passed. ECLAC contends that this recovery must go hand in hand with a structural transformation that will narrow and then close the three gaps associated with the region's dysfunctional economic model. ECLAC has referred to this strategy as a transformative recovery for advancing towards a sustainable form of development because it combines economic recovery with an effort to supersede the region's current development style (ECLAC, 2020i).

ECLAC has proposed four lines of action for addressing the most pressing impacts of the pandemic. The first is the provision of a basic income as an emergency social protection measure. The second is the distribution of an anti-hunger grant. The third is a policy package designed to support business networks and segments of the workforce that are at risk of swelling the ranks of the unemployed. The fourth is a set of measures to strengthen the role of international financial institutions in helping to meet global borrowing requirements. 
From a medium- and long-term standpoint, ECLAC has espoused the view that a socially, economically and environmentally sustainable development process is not something that unregulated markets can achieve on their own. Public policies need to be introduced in a range of different areas at the same time in order to advance innovation in the region and bring its technology up to date, help to shape a welfare state that will support learning and equality, redesign economic incentives to underpin environmental protection, and apply macroprudential policies to provide stability and promote competitiveness, progressive fiscal policies that will promote equality while providing financing for public investments and sectoral policies that will help the sectors that are the main drivers of sustainability to grow. These policies need to be interconnected and based on complementarities and synergies that will leverage what ECLAC has described as a "big push for sustainability".

The sectoral dimension of these policies is of crucial importance. The transition towards sustainable development will call for efforts to enable strategic sectors to make a greater contribution to GDP while strongly discouraging others, whether for environmental reasons, considerations of equality or on technological grounds.

ECLAC has identified seven sectors that are of strategic importance for the transition to sustainable development because of their attributes in the areas of competitiveness, employment, equality, decarbonization and/or environmental sustainability:

- A transition to non-conventional renewable energy sources in order to establish a sustainable energy matrix

- Sustainable mobility in urban areas

- An inclusive and innovative digital economy as a driver of growth and sustainability

- The health-care manufacturing industry

- The bioeconomy for sustainable development based on biological resources and natural ecosystems

- A circular economy to promote recycling

- Sustainable tourism

These activities should be the focus of industrial and technology policies. Policy incentives should be configured to promote these sectors, and public investment should play an important role in attracting private investment and supporting effective demand during the crisis.

Finally, this transformative transition will call for political compacts that provide for expansionary, progressive, effective and efficient fiscal policies. Leadership cadres are needed that will provide greater certainty, that know how to build partnerships, reshape politics and promote well-being, foster solidarity among nations, strengthen regional integration, fulfil international agendas (including the 2030 Agenda for Sustainable Development) and transmute emergency measures into drivers of the recovery.

\section{Bibliography}

Abeles, M., E. Pérez Caldentey and G. Porcile (2020), "The COVID-19 crisis and the structural problems of Latin America and the Caribbean: responding to the emergency with a long-term perspective", CEPAL Review, No. 132, special edition, Santiago, Economic Commission for Latin America and the Caribbean (ECLAC). Alarco, G. (2014), "Wage share and economic growth in Latin America, 1950-2011", CEPAL Review, No. 113 (LC/G.2614-P), Santiago, Economic Commission for Latin America and the Caribbean (ECLAC).

Bárcena, A. (2020), "ALC ante la crisis de la COVID-19: cómo debe ser la reactivación", Revista Pensamiento Iberoamericano: Iberoamérica ante la pandemia, 3ra Época - 01/2020.

Blanchard, O. and L. Summers (1986), "Hysteresis and the European unemployment problem", NBER Macroeconomics Annual, vol. 1, Cambridge, MIT Press. 
Blecker, A. and R. Setterfield (2019), Heterodox Macroeconomics: Models of Demand, Growth and Distribution, Massachusetts, Edward Elgar Publishing.

Cimoli, M. and G. Porcile (2014), "Technology, structural change and BOP constrained growth: a structuralist toolbox", Cambridge Journal of Economics, vol. 38, No. 1.

Cimoli, M., J.B. Pereima and G. Porcile (2019), "A technology gap interpretation of growth paths in Latin America and Asia", Research Policy, vol. 48.

ECLAC (Economic Commission for Latin America and the Caribbean) (2020a), "Latin America and the Caribbean and the COVID-19 pandemic: Economic and social effects", Special Report COVID-19, No. 1, Santiago, April.

_ (2020b), "Measuring the impact of COVID-19 with a view to reactivation", Special Report COVID-19, No. 2, Santiago, April.

(2020c), "The social challenge in times of COVID-19", Special Report COVID-19, No. 3, Santiago, May. (2020d), "Sectors and businesses facing COVID-19: Emergency and reactivation", Special Report COVID-19, No. 4, Santiago, July.

(2020e), "Addressing the growing impact of COVID-19 with a view to reactivation with equality: New projections", Special Report COVID-19, No. 5, Santiago, July.

(2020f), "The effects of the coronavirus disease (COVID-19) pandemic on international trade and logistics", Special Report COVID-19, No. 6, Santiago, August.

_ (2020g), "Universalizing access to digital technologies to address the consequences of COVID-19", Special Report COVID-19, No. 7, Santiago, 26 August.

_ (2020h), Economic Survey of Latin America and the Caribbean, 2020 (LC/PUB.2020/12-P), Santiago. (2020i), Building a New Future: Transformative Recovery with Equality and Sustainability (LC/SES.38/3-P/Rev.1), Santiago.

(2020j), Preliminary Overview of the Economies of Latin America and the Caribbean, 2020 (LC/PUB.2020/17-P), Santiago.

Fajnzylber, F. (1990), "Industrialization in Latin America: from the 'black box' to the 'empty box': a comparison of contemporary industrialization patterns”, Cuadernos de la CEPAL series, No. 60 (LC/G.1534/Rev.1-P), Santiago, Economic Commission for Latin America and the Caribbean (ECLAC), August.

Murillo, G. (2011), "Recordando la gripe española", Medicina Interna de México, vol. 27, No. 5, Mexico City.

Ocampo, J. A. (2020), "International financial cooperation to address the Latin American economic crisis", CEPAL Review, No. 131 (LC/PUB.2020/9-P), Santiago, Economic Commission for Latin America and the Caribbean (ECLAC).

Prebisch, R. (1963), Hacia una dinámica del desarrollo latinoamericano, Mexico City, Fondo de Cultura Económica. _(1962), "El desarrollo económico de la América Latina y algunos de sus principales problemas", Boletín Económico de América Latina, vol. 7, No. 1, February.

Rodríguez, O. (2006), El estructuralismo latinoamericano, Mexico City, Siglo XXI. (1977), "Sobre la concepción del sistema centro-periferia", CEPAL Review, No. 3, Santiago, Economic Commission for Latin America and the Caribbean (ECLAC).

Seers, D. (1962), "A Model of comparative rates of growth in the world economy", The Economic Journal, vol. 72, No. 285, 1 March.

Setterfield, M. (2009), "Path dependency, hysteresis and macrodynamics", Path Dependency and Macroeconomics, P. Arestis and M. Sawyer (eds), London, Palgrave Macmillan.

Thirlwall, A. (1979), "The balance of payments constraint as an explanation of international growth rate differences", BNL Quarterly Review, vol. 32, No. 128, Banca Nazionale del Lavoro.

Torres, M. (2019), “Globalización, capitalismo transnacional y dependencia: el itinerario de una 'visión'”, Del estructuralismo al neoestructuralismo: la travesía intelectual de Osvaldo Sunkel, A. Bárcena and M. Torres (eds), Santiago, Economic Commission for Latin America and the Caribbean (ECLAC). 